Recent Progress on the Devel opment of Ant i bi ot i cs from the Genus Mcromonospora

\begin{tabular}{|c|c|}
\hline 著者 & $\begin{array}{l}\text { Boumehi ra Al i Zi neddi ne, El - Enshasy Hesham } \\
\text { Al i , Hacene Hoci ne, El sayed El sayed Ahned, } \\
\text { Azi z Ramh an, Park Enoch Y. }\end{array}$ \\
\hline $\begin{array}{l}\text { j our nal or } \\
\text { publ i cat } i \text { on title }\end{array}$ & Bi ot echnol ogy and Bi opr ocess Engi neer i ng \\
\hline vol une & 21 \\
\hline nunber & 2 \\
\hline page $r$ ange & 199-223 \\
\hline year & 2016-05- 22 \\
\hline 出版者 & Spr i nger Nat ure \\
\hline 権利 & $\begin{array}{l}\text { (C) The Kor ean Soci ety for Bi ot echnol ogy and } \\
\text { Bi oengi neer i ng and Spr i nger-Ver I ag Ber I i n } \\
\text { Hei del berg } 2016\end{array}$ \\
\hline URL & ht t p: //hdl . handl e. net /10297/10131 \\
\hline
\end{tabular}




\title{
Recent Progress on the Development of Antibiotics from the Genus Micromonospora
}

\author{
Ali Zineddine Boumehira, Hesham Ali El-Enshasy*, Hocine Hacene, Elsayed Ahmed \\ Elsayed, Ramlan Aziz and Enoch Y. Park*
}

E-mail:

zineddine@ibd.utm.my (AZB)

henshasy@ibd.utm.my (HAE)

h hacene@yahoo.fr $(\mathrm{HH})$

eaelsayed@ksu.edu.sa (EAE)

ramlan@ibd.utm.my (RA)

park.enoch@shizuoka.ac.jp (EYP)

Ali Zineddine Boumehira, Hesham Ali El-Enshasy ${ }^{*}$, Ramlan Aziz

Institute of Bioproduct Development, Universiti Teknologi Malaysia (UTM), Skudai 81310 Johor, Malaysia.

Tel.: +60 75531573.

E-mail: henshasy@ibd.utm.my

Ali Zineddine Boumehira,

Centre de Recherche Scientifique et Technique en Analyses Physico Chimiques, Bou-Ismail, Tipaza, Algeria.

Ali Zineddine Boumehira, Hocine Hacene

University of Sciences and Technology Houari Boumediene, FSB, LBCM, Bab Ezzouar, Algiers, Algeria.

Hesham Ali El-Enshasy

City of Scientific Research and Technology Applications, New Burg Al Arab, Alexandria, Egypt.

Elsayed Ahmed Elsayed

Faculty of Science, King Saud University, Riyadh, Saudi Arabia.

Elsayed Ahmed Elsayed

Natural and Microbial Products Department, National Research Center, Dokki, Cairo, Egypt.

Enoch Y. Park*

Research Institute of Green Science and Technology, Shizouka University, 836 Ohya, Suruga-ku, Shizuoka 4228529, Japan

Tel.: +81 54238 4887; fax: +81 542384887 .

E-mail: park.enoch@shizuoka.ac.jp 
Abstract The emergence of large number of antimicrobial-resistant organisms has given alarming magnitude. Nature is historically the source of drugs, and microorganisms have provided a significant number of antibiotic compounds, which are used every day in the treatment of many infectious diseases. However, the introduction to the pharmaceutical market of new therapeutic molecules has largely decreased during the last two decades. In this review, antibiotics from the genus Micromonospora are recognized as potential biofactory for new antibiotic production. The Micromonospora has been deeply studied and more than 100 antibiotics isolated from different Micromonospora strains. In addition, comprehensive information about the recent development in the field of analytical, biological and bioinformatics screening tools, which recently used in the discovery of new therapeutic compounds, are provided. It is widely believed that reviving old antibiotics produced by Micromonospora is possible and the study of this genus is still interesting for novel bioactive molecules discovery.

Keywords: Micromonospora, antibiotics, drug discovery, gentamicin, secondary metabolites, natural products. 


\section{Introduction}

The emerging of antimicrobial-resistant organisms became one of the major problem in the treatment of many infectious diseases [1-3]. In December 2014, a report commissioned by the British Prime Minister, David Cameron, under the title "Antimicrobial Resistance: Tackling a crisis for the health and wealth of nations", was published. This report estimates that drug-resistant infections can cause supplement of 10 million deaths annually and an economic loss of over 100 trillion USD in 2050 [4,5]. On the other hand, the introductions of new antibiotics into therapy market have significantly decreased during the last twenty years, because of limitations of drug discovery programs and inappropriate economic-regulatory environment [6-9]. Natural products are an essential source of compounds for drug discovery. In addition to plants, microorganisms provided a large number of therapeutic molecules $[10,11]$. Recently, a team led by Kim Lewis of Northeastern University in Boston, Massachusetts, have published in Nature, the discovery of a new antibiotic called teixobactin, with a new mechanism of action, via a new discovery technology. This was the first new antibiotic of high therapeutic potential since 1987 [8,12].

After the discovery of Gentamicin, the genus Micromonospora became an important source in the drug discovery process. Nowadays, more than 740 antibiotics have been isolated from Micromonospora strains [13,14]. In this review, we proceed to summarize briefly the most important antibiotics produced by Micromonospora species, and we give an update about the different strategies that can be used in the development of new antibiotics from this genus.

\section{The Genus Micromonospora}

The genus Micromonospora, a member of the family Micromonosporaceae, was initially described by Ørskov in 1923 [15-17]. The species belong to this genus are Gram positive 
bacteria, aerobic to microaerophilic, chemo-organotrophic, sensitive to $\mathrm{pH}$ below 5.0 and have optimal temperature between 20 and $40^{\circ} \mathrm{C}$. Several strains produce carotenoid mycelial pigments, giving the colony which gives different characteristics colors range such as yellow, red, orange, brown, purple or black. From its name, this genus produces singly spore directly attached to substrate mycelium or carried out short sporophore. The cell wall of Micromonospora contains meso-diaminopimelic acid and/ or 3-OH-diaminopimelic acid. The major phospholipids are phosphatidylethanolamine, phosphatidylinositol, and phosphatidylinositol mannosides [16,17]. The first species of this genera Micromonospora chalcea described by Ørskov [15], was isolated by Foulerton in 1905 and classified under the name Streptothrix chalceae [18]. This remained the only known strain among the actinomycetes bearing the generic name Micromonospora until Jensen in 1930 described a large number of soil micro-organisms which corresponded with Ørskov's description [19]. At the time of writing, the genus consisted of 61 validly named species (http://www.bacterio.net) [20], in addition to the recently described species, like: M. spongicola [21], M. jinlongensis [22], M. zeae [23], M. maoerensis [24], M. endophytica [25], M. palomenae [26], M. harpali [26], M. oryzae [27], M. vulcania [28], M. fluostatini [29], M. nickelidurans [30], M. zhanjiangensis [31].

\section{Antibiotic from the genus Micromonospora}

Actinomycetes are considered as the most important biofactory for therapeutic secondary metabolites production, and most of antibiotic discovery researches are usually focus on the isolation of novel secondary metabolites from actinomycetes. After the discovery of Gentamicin, the genus Micromonospora became an important resource of natural molecules. Table 1 shows the most known antibiotics isolated from different strains of the genus Micromonospora. It summarizes the chemical class, and producer strain, source of isolation 
from Micromonosporin, antibiotic compound isolated and described in 1947 by Waksman et al. [32] to the recently discovered compounds such as Neomacquarimicin [33].

The aminoglycosides are one of the widely known classes of antibiotics and include many members widely used in the treatment of infectious diseases caused by Gram-positive and Gram-negative bacteria. The mode of action is mediated through targeting the bacterial ribosome, where they bind to the A-site and interrupt protein synthesis. Aminoglycosides are produced essentially by Streptomyces and soil Micromonospora strains [34-39].

The most famous antibiotics produced by the genus Micromonospora are Gentamicins [40]. The success of this mixture of aminoglycosides is based on the wide spectrum activity against Gram-positive and Gram-negative bacteria. The antibiotic mixture was isolated for the first time from two strains: M. echinospora (former purpurea) NRRL 2953 and $M$. echinospora NRRL 2985 from soil sample in New York, USA [40-42]. Gentamicins are water soluble antibiotic complex, with main constituents of gentamicin $\mathrm{C}$ complex $\mathrm{C} 1, \mathrm{C} 2$, $\mathrm{C} 1 \mathrm{a}, \mathrm{C} 2 \mathrm{a}$, and $\mathrm{C} 2 \mathrm{~b}$. The chemical structure of this compound is characterized by a central diaminogenouscyclitol (2-deoxystreptamine (2DOS) 4,6-disubstituted with the auxiliary sugars garosamine and purpurosamine, Fig. 1(A). In addition to gentamicin $\mathrm{C}$ complex, many minor components like gentamicins A, B, and X, are used as starting materials for the development of antiprotozoal drugs $[43,44]$. Gentamicin, was introduced into the pharmaceutical market in 1971 and has been widely used in many medical applications since that time [45]. Currently, Gentamicin is part of the essential drug list of the World Health Organization [46]. In addition, new gentamicin-conjugants exhibit anti-viral effects (anti-HIV) [43,44], and can be also used in genetic therapeutic approaches [47]. In addition, gentamicin was also used successfully in agriculture applications [48].

Antibiotic G-418 (geneticin), is similar structure to gentamicin B1 and produced by $M$. rhodorangea. In addition to its wide spectrum antibiotic activity active against Gram positive 
and Gram negative bacteria, it exhibits also some activity against eukaryotic organisms such as Protozoa and Helminths $[41,49,50]$. The antileishmanial activity of G-418 (against Leishmania major and Leishmania donovani) is more potent than neomycin and gentamicin [39]. In addition, G-418 is used as an agent for selection in cell culture protocols [51]. Another antibiotic related to gentamicins production is Antibiotics JI-20 (A and B). This antibiotic was first detected during the cultivation of a mutant strain of $M$. echinospora JI-20 (NRRL 2953) [52]. Other antibacterial compound named as Antibiotic 460, was produced by M. chalcea subsp. flavida NRRL 3222 [53].

Sisomicin is also belongs to aminoglycosides with chemical structure close to gentamicin $\mathrm{C} 1 \mathrm{a}$ and differs by the presence of an unsaturated sugar ring I, Fig. 1(B) [54-57]. The antibacterial activity of sisomicin is higher than other structurally related aminoglycosides like gentamicin, tobramycin, and amikacin [57]. Tansarli et al. [58] that sisomicin displayed in vitro activity against $41 \%$ of Enterococcus spp., 97\% of Staphylococcus spp., and was effective when applied in cream form in the treatment of many diseases. Antibiotic G-52, was produced with sisomicin by M. zionensis NRRL 5466, this antibiotic is active against Grampositive and Gram-negative bacteria $[59,60]$. Verdamicin is other antibiotic derived from the gray-green colony of M. grisea NRRL 3800. This antibiotic demonstrated activity similar to that of gentamicin against members of the family Enterobacteriaceae and against Pseudomonas aeruginosa $[41,61,62]$. Sagamicin (XK-62-2), is other important antibiotic produced by soil isolates of $M$. sagamiensis subsp. nonreducans ATCC 21803 and $M$. sagamiensis ATCC $21826[63,64]$. In 2002, Marone et al., compared the in vitro antibacterial activity of sagamicin, gentamicin, tobramycin and norfloxacin. Sagamicin was one of the most effective compound against Enterobacteriaceae with a $\mathrm{MIC}_{90}$ of $2 \mathrm{mg} / \mathrm{L}$ and presented good antipseudomonal activity similar or higher to that of gentamicin [65]. Fortimicins A, B, $\mathrm{C}, \mathrm{D}$, and $\mathrm{KE}$ are also aminoglycoside antibiotics produced by $\mathrm{M}$. olivasterospora MK-70 
(ATCC 21819) [66-70]. Girolami et al. (1977), showed that the antibacterial effect of fortimicin A against Enterobacteriaceae is comparable to amikacin [71]. Other research reported also the bactericidal effect of Fortimicin A against Staphylococcus epidermnidis [72]. Antlermicins A, B and C are antitumor antibiotics produced by soil isolate of $M$. chalcea subsp. kazitnoensis T-90 [73,74]. Tetrocarcins A, B, C, E1, E2, F and F-1, were first isolated from M. chalcea KY11091 and exhibited antibacterial activity against Gram-positive bacteria [75-77]. The tetrocarcin was effective against different experimental tumor models as mouse sarcoma 180 and mouse leukemia P388 [75,78,79].

Combimicins, A1, A2, B1 and B2 are named after their hybridized structure of kanamycins and gentamicins. These antibiotics were obtained by growing gentamicin producer strain, Micromonospora sp. ATCC 31348, or its gentamicin non-producing mutant Micromonospora sp. ATCC 31349. Combimicins have strong antibacterial activities against Gram-positive and Gram-negative bacteria [80]. AC6H is antitumor antibiotic, produced by M. carbonaceae subsp. carbonaceae K55-AC6. The cytotoxicity of AC6H against P388 leukemia and B16 melanoma cells were 6.25 and $25 \mu \mathrm{g} / \mathrm{mL}$, respectively [81].

Macrolide antibiotics are part of the polyketide group of natural products. The antimicrobial activity of macrolides is mediated through their binding ability to the $50 \mathrm{~S}$ subunit of the bacterial ribosome which inhibits ribosomal translocation, leading to inhibition of bacterial protein synthesis. Macrolides were also used for the treatment of non-infectious diseases based on their anti-inflammatory and immunomodulatory effects in humans. They can inhibit the production of many pro-inflammatory cytokines such as: IL-1, IL-6, IL-8, and (TNF)- $\alpha$ [82]. Megalomicins $\mathrm{A}, \mathrm{B}, \mathrm{C}_{1}$ and $\mathrm{C}_{2}$, are produced by $M$. megalomicea strains isolated from soil. Megalomicins are characterized by their antiparasitic, antibacterial and antiviral properties [83-87]. 
Rosamicin (Rosaramicin), isamacrolide antibiotic produced by M. rosaria NRRL 3718, in mixture with other minor secondary metabolites [88-91]. The chemical and biological characteristics these compounds are close to erythromycin, Fig. 1(C). Rosamicin have an antibacterial effect against Staphylococcus aureus, S. epidermidis, and enterococci [92,93]. Juvenimicins, antibacterial antibiotics were produced by $M$. chalcea subsp. izumensis ATCC 21561 which was initially isolated from soil sample [94,95]. Juvenimicin C and 5-O- $\alpha$-Lrhamnosyltylactone, were obtained from the culture broth of Micromonospora sp. The antibiotic Juvenimicin C improved quinone reductase $1(\mathrm{QR} 1)$ enzyme, which is known to have the potential of mediating cancer chemopreventive activity [96].

Mycinamicins were isolated from the culture broth of M. grisseorubida A11725 [97]. This speices was able to produce several type of mycinamicins, the strctures of these compounds were published by many authors [97-109].

The antitumor antibiotics Calicheamicins ( $\beta$ 1Br, $\gamma 1 \mathrm{Br}, \alpha$ II, $\alpha$ 3I, $\beta$ 1I, $\gamma$ 1I and $\delta 1 \mathrm{I})$, were obtained from the culture broth of M. echinospora subsp. calichensis. Calicheamicin $\gamma$ 1I, Fig. 1(D) exhibited antitumor activity against P388 leukemia and B16 melanoma in in vivo testing. In murine tumor models, it was more effective than Adriamycin, the widely applied antitumor antibiotic in clinical applications [110-112]. Calicheamicins can be used for targeted delivery, through the process of monoclonal antibody conjugation using a hydrazone cleavable linker [113]. This ability was used to conjugate calicheamicin with monoclonal antibodies recognizing CD33 expressed on myeloid progenitors in patients with acute myeloid leukaemia (AML), the result was the active agent of gemtuzumab ozogamicin (Mylotarg $\left.^{(}\right)$. In May 2000, the U.S. Food and Drug Administration (FDA) approved this antibiotic under the accelerated approval program to treat patients who are 60 years and older in first relapse with CD33+ AML and not considered candidates for chemotherapy [114]. 
However, in 2010, Pfizer Inc. announced the voluntary withdrawal from the U.S. market after questionable safety and efficacy data in post-approval studies [115-117].

Izumenolide, Fig. 1(E), is a potent inhibitor of $\beta$-lactamases, especially when applied in Gram-negative bacteria. This antibiotic produces by M. chalcea subsp. izumensis SC 11133 [118-121]. Dotriacolide is also $\beta$-lactamases inhibitors produced by M. echinospora MG299fF35. Dotriacolide is resembles to izumenolide but differs in the number of the O-sulfate groups and the ring size of the lactone [122]. It was found that dotriacolide enhanced mycinamicin production in M. griseorubida [123].

Rustmicin (galbonolide A), is an antifungal antibiotic, with insignificant inhibitory effect on bacterial cell. This antibiotic is produced by M. chalcea 980-MC1 [124,125]. Clostomicins $\left(\mathrm{A}, \mathrm{B}_{1}, \mathrm{~B}_{2}, \mathrm{C}\right.$ and $\left.\mathrm{D}\right)$ are a macrolide antibiotics produce by $M$. echinospora subsp. armeniaca KMR-593. Clostomicins exhibited strong antibacterial activities against Gram-positive anaerobic bacteria such as Clostridium perfringens and C. difficile [126,127]. Quinolidomicins $\left(\mathrm{A}_{1}, \mathrm{~A}_{2}\right.$ and $\left.\mathrm{B}_{1}\right)$, were isolated from the fermentation broth of Micromonospora sp. JY16 - FERM BP-3940. Quinolidomicin A1 inhibited the growth of different tumor cells including multidrug-resistant cells. Quinolidomicin $\mathrm{B}_{1}$ was similarly cytotoxic, while Quinolidomicin A2 was inactive against tumor cells [128,129].

Pyrrolosporin A is antibiotic compound with antibacterial and antitumor properties. This molecule was obtaiend from soil isolate of Micromonospora sp. 2C39217-R109-7 (ATCC 53791) [130-132]. Cymbimicin A and B are cyclophilin-binding structures, they were isolated from the culture broth of Micromonospora sp. A92-313709 (DSM 8594). However, cymbimicin $\mathrm{A}$ is more biologically active but with six fold lower activity compared to cyclosporin A [133]. IB-96212, has been isolated from the fermentation broth of a marine Micromonospora sp. L-25-ES25-008. This macrolide showed a very strong cytotoxic activity against P388 cell lines $[134,135]$. Arisostatins (A and B) are members of tetrocarcin class of 
antibiotics and were isolated from the culture broth of a Micromonospora sp. TP-A0316 strain. Arisostatins showed antibiotic activity against Gram-positive bacteria as well as antitumor effects $[136,137]$. It was found that Arisostatin A induces apoptosis through the activation of caspase-3 and reactive oxygen species generation in AMC-HN-4 cells [138]. Micromonosporin A is a 24-membered polyene lactam macrolide, isolated from the Micromonospora sp. TT1-11 [139]. Recently, Levantilide C, 20-membered macrolide, was isolated from the Micromonospora sp. FIM07-0019. Levantilide C exhibited moderate antiproliferative activity against several tumor cell lines [140].

Everninomicins (A-E), are complex oligosaccharide antibiotics, produced by $M$. carbonacea NRRL 2972 and M. carbonacea subsp. aurantiaca NRRL 2997 [141,142]. The Everninomicin (SCH27899), Fig. 1(F) is produced by M. carbonacea var. africana ATCC 39149 [143]. Based on in vitro study, everninomicins B and D are active against all Grampositive bacteria, Neisseria, and Bacteroides [144]. A multinational study of a total of 33 laboratories demonstrated that evernimicin possesses high antimicrobial activity against Gram-positive organisms, which was higher than that of vancomycin [145]. However, the clinical development of evernimicin (Ziracin) was discontinued in Phase III clinical trials, one of the reason, it could not be formulated reproducibly to be used as an intravenous drug $[146,147]$. Trehazolin, is a pseudodisaccharide, Fig. $1(\mathrm{G})$ and was first isolated from the culture broth of Micromonospora sp. SANK 62390. The antibiotic properties of this compound is mediated through trehalase glycosidase inhibition activity [148]. Trehalamine, was obtained by acid hydrolysis of trehazolin. Even though, it is poor inhibitor of trehalase but it inhibits more potently rat intestinal sucrase $\left(I_{50} 6.8 \times 10^{-5} \mathrm{M}\right)$ than trehazolin [149].

Halomicins A, B, C and D belong to the group of ansamycin antibiotics, are produced by M. halophytica subsp. halophytica NRRL 2998 and M. halophytica subsp. nigra NRRL 3097. These antibiotics are highly active against Gram-positive bacteria. The structure of Halomicin 
A is shown in Fig. $1(\mathrm{H})[41,150,151]$. Micromonospora produced also oxazoles such as LLE19085 alpha and Citreamicins $(\alpha, \beta, \gamma, \zeta$ and $\eta)$. These compounds were isolated from the fermentation broth of $M$. citrea NRRL 18351 [152,153].

Some species of the genus Micromonospora produce thiopeptide antibiotics, like, Sch 40832, which produced by M. carbonecea var. africana ATCC 39149. It has potent in vitro activity against Gram-positive bacteria [154-156]. The dipeptide, N-(2,6-diamino-6hydroxymethylpimelyl)-L-alanine, was isolated from the culture broth of M. chalcea PA3534. It exhibits antibacterial activity against E. coli, and the activity is synergistically enhanced when applied with cell wall synthesis-inhibitors [157]. The amino acid L-2-(1methylcyclopropyl)glycine, produce by M. miyakonensis PA-4046, has also antibacterial activity $[158,159]$. The inhibitor of angiotensin I converting enzyme (ACE), K-13, is a cyclic dipeptide, isolated from the culture broth of, M. halophytica subsp. exilisia K-13 [160,161]. The antifungal compound Sch 37137 was isolated from the cultured broth of Micromonospora sp. SCC 1792 [162]. The antitumor antibiotic Korkormicins, are cyclic depsipeptides complex, produced by Micromonospora sp. C39500. The major component of the complex, korkormicin A, showed high in vivo antitumor activity against P388 leukemia and M109 lung carcinoma. Thus, it considered as potential antitumor agent for cancers with wild type p53 [163-166]. Rakicidin A is a cytotoxic agent and isolated from culture broth of a Micromonospora sp. R385-2 [167-169] and characterized by cyclic depsipeptide structure $[167,170,171]$. Thiocoraline, Fig. $1(\mathrm{I})$ is a thiodepsipeptide and produced by both of Micromonospora sp. ACM2-092 and Micromonospora sp. ML1. It showed potent cytotoxic activity against P-388, A-549 and MEL-28 cell lines, and exhibits a strong antibacterial activity against Gram-positive bacteria [172-175]. The antitumor activity of this antibiotic is mediated via DNA polymerase alpha inhibition and characterized by high cytotoxic potency against cancer cells $[176,177]$. Recently, it was reported that thiocoraline exhibits cytotoxic 
activity in BON and $\mathrm{H} 727$ cells, activates the Notch pathway in carcinoids and reduces tumor progression $[178,179]$. Maklamicin was obtained from the culture broth of the endophytic strain Micromonospora sp. GMKU326. It demonstrates antibacterial activity against Grampositive bacteria [180].

M-92, is a Naphthoquinones antibiotic complex, produced by M. verruculosa MCRL 0404. The six major components of the complex antibiotic have a similar type of antimicrobial spectrum. Between these components, VA-2 exhibited the most effective antimicrobial and antitumor activities [181-183]. Another Naphthoquinone, Crisamicin A, Fig. 1(J), is produced by M. purpureochromogenes subsp. halotolerans RV-79-9-101. It showed in vitro activity against Gram-positive bacteria, B16 murine melanoma cells, and herpes simplex, vaccinia, and vesicular stomatitis viruses [184,185]. 9-Hydroxycrisamicin A, was extracted from the broth of Micromonospora sp. SA246. This compound exhibited antibacterial and cytotoxic activity [186]. Yoon et al. (2004), found that 9-hydroxycrisamicinA, showed potential for activating hepatitis B virus (HBV) replication [187]. K-259-2, an Anthraquinone, is inhibitor of $\mathrm{Ca}^{2+}$ and calmodulin-dependent cyclic nucleotide phosphodiesterase, it was obtained from the fermentation broth of M. olivasterospora K-259 [188]. Dynemicin A, was isolated from the culture broth of M. chersina ATCC 53710 and exhibited antibacterial and cytotoxic activity [189-191]. Deoxy-dynemicin A, was produced together with dynemicin A in culture of M. globosa FERM P-10651 [192]. Lupinacidins A, B and $\mathrm{C}$, are produced by M. Iupini Lupac 08, isolated from root nodules of Lupinus angustifolius collected in the mid-west Spain [193,194]. Lupinacidin C displayed a potent anti-invasive activity against murine colon 26-L5 carcinoma cells [194].

Streptonigrin and 7-(1-methyl-2 oxopropyl) streptonigrin are two other bioactive compounds produced by Micromonospora sp. IM 2670. Streptonigrin can induce apoptosis through a p53-dependent pathway in human neuroblastoma cells [195]. The quinocycline 
antibiotic Kosinostatin, was isolated from the culture broth of Micromonospora sp. TPA0468. It showed antibacterial and cytotoxic activity [196,197]. Spartanamicins A and B, are two antifungal anthracycline antibiotics produced by Micromonospora sp. ATCC 53803, isolated from a potted soil containing asparagus (Asparagus officinalis L.) plants [198]. Cororubicin, Fig. 1(K), generated superoxide radicals in KB human epidermoid cancer cells and N18-RE-105 neuronal hybridoma cells, and showed cytotoxicity. This antibiotic is produced by Micromonospora sp. JY16 isolated from soil [199]. Micromonomycin is antibacterial anthracycline compound, showed potent inhibitory activity against S. aureus, Streptococcus pneumoniae, and supersensitive E. coli, and also displayed weak antifungal activity against S. cerevisiae and C. albicans [200]. In 2012, Sousa et al., isolated Micromonospora strains associated with the tunicate Eudistoma vannamei and can produce four new anthracyclinones, two of them were cytotoxic against human colon adenocarcinoma cell line HCT-8 [201].

Hazimicins, a class of broad spectrum antibiotics, were isolated from the culture broth of M. echinospora var. challisensis SCC 1411 [202]. The nucleoside antibiotics, Dapiramicin A and B, have been isolated from the fermentation broth of Micromonospora sp. SF-1917. Dapiramicin A was highly effective in the control of sheath blight, a destructive disease of rice plants caused by Rhizoctonia solani, in a pot test [203,204]. Neihumicin was isolated from the fermentation broth of $M$. neihuensis $\mathrm{Wu} \mathrm{NH3-1} \mathrm{and} \mathrm{shows} \mathrm{in} \mathrm{vitro} \mathrm{cytotoxicity}$ against KB tissue culture cells as well as antifungal activity against S. cerevisiae ATCC 9763 [205-207]. Sibanomicin, is a pyrrolo-[1,4]-benzodiazepine antitumor antibiotic produced by a culture of Micromonospora sp. SF2364 [208]. Macquarimicins (A, B and C), were produced by the two strains M. chalcea AB 965S-73 and M. chalcea AB 969J-62. Macquarimicin B has inhibitory activity against the leukemia cell line P-388 [209,210]. A naturally occurring dibenzodiazepine, BU-4664L, was produced in fermentation broth of Micromonospora sp. 
ATCC 55378. The compound possesses anti-inflammatory and anti-tumor activities [211]. The initial structure assigned for BU-4664L was revised by Igarashi et al. [212]. In 2010, Miyanaga et al. demonstrated that BU-4664L suppresses invasion and angiogenesis in vitro. It inhibited the gelatinase activities of MMP-2 and MMP-9 with an IC50 value of $0.46 \mu \mathrm{g} / \mathrm{mL}$ and $0.60 \mu \mathrm{g} / \mathrm{mL}$, respectively [213].

YM-47515, is an isonitrile antibiotic, produced by M. echinospora subsp. echinospora Y-03559J and showed antimicrobial activity against Gram-positive bacteria [214]. The antibiotic glutarimide streptimidone, Ao58A, showed a high antifungal activity against some plant pathogenic fungi and inhibit the growth of Phytophthora capsici, Didymella bryoniae, Magnaporthe grisea, and Botrytis cinerea in the range of $3-10 \mu \mathrm{g} / \mathrm{mL}^{-1}$ of MICs [215]. Bravomicins, are obtained by fermentation of a strain of $M$. polytrota, isolated from soil sample. Six bioactive compounds, designated bravomicins (A-F), are obtained and found to have antibacetrial activity against methicillin resistant S. aureus (MRSA) and multiply resistant E. faecium (MREF) [216]. The initial structure proposed by the US 5,994,543 patent, was revised by Banskota et al. (2009), and they also suggested a strong similarity between the structures of TLN-05220, echinosporamicin and bravomicin A [217]. Staurosporine, 4'-Nmethyl-5'-hydroxystaurosporine and 5'-hydroxystaurosporine, were produced by the marine strain, Micromonospora sp. L-31-CLCO-002, isolated from Sponge Clathrina coriacea. They showed cytotoxic activity [218]. SB-219383, the potent and selective inhibitor of bacterial tyrosyl-tRNA synthetase, was isolated from Micromonospora sp. NCIMB 40684 [219,220]. Lomaiviticins A and B, are produced by M. lomaivitiensis LL-37I366, isolated from ascidian Polysyncraton lithostrotum. Lomaiviticin A and B were demonstrated to be potent DNA damaging agents by the biochemical induction assay (BIA). Lomaiviticins $\mathrm{C}-\mathrm{E}$, were isolated recently by Woo et al. (2012). It was found that the dimeric diazofluorene of (-)lomaiviticin exhibit antiproliferative activity [221,222]. The lomaiviticin A was also tested 
against different cancer cell lines and showed cytotoxicity with IC50 values ranging between 0.01 and $98 \mathrm{ng} / \mathrm{mL}$. Lomaiviticins A and B showed also antibacterial activity against Grampositive bacteria [223].

$\mathrm{R} 176502$, is an antiproliferative bafilolide metabolite, extracted from liquid cultures of Micromonospora sp. JS1035 [224]. Sch725418, is a Diketopiperazine, isolated from Micromonospora sp. It exhibits inhibitory activity against a supersensitive strain of $S$. cerevisiae [225]. Echinosporamicin, an antibiotic produced by M. echinospora subsp. echinospora LL-P175, contain aromatic polycyclic system and a piperazinone moiety. It exhibited potent activity against methicillin-resistant Staphylococci and vancomycin-resistant Enterococci strains [226]. Diazepinomicin is a dibenzodiazepine alkaloid compound originally isolated from a marine Micromonospora sp. DPJ12 [227]. It was also produced by Micromonospora sp. RV115 strain isolated from the sponge Aplysina aerophoba [228]. Preclinical data demonstrated that diozepinomicin is a targeted anticancer drug with dual activity: selective binding to the peripheral benzodiazepine receptor (PBR), which induces tumor apoptosis, and inhibition of the Ras/MAP kinase signaling pathway [229]. It showed also antioxidant activity for diazepinomicinin human kidney (HK-2) and human promyelocytic (HL-60) cell lines. In addition, it exhibits antiparasitic activity against trypomastigote forms of Trypanosoma brucei with IC50 of $13.5 \mathrm{mM}$ [230]. Retymicin, Galtamycin B, Saquayamycin Z and Ribofuranosyllumichrome, were produced by Micromonospora sp. Tü 6368. Retymicin, galtamycin B and saquayamycin Z show cytostatic activity against several human tumor cell lines [231,232].

In addition to these compounds, many other antibiotics previously produced by other actinomycetes were also produced by Micromonospora. Neomycin B, which was isolated originally from Streptomyces fradiae in 1949, was also found in the culture broth of Micromonospora sp. 69-683 [233]. The comparison of aminoglycoside acetyltransferase- 
encoding gene (aac), and aminoglycoside phosphoryltransferase gene (aph) of Streptomyces fradiae and Mcromonospora chalcea indicates considerable divergence [234,235]. Others antibiotics produced by other genera were also reported by genus Micromonospora. These include Primycin [41,236], Rifamycins [41,237,238], Erythromycin B [41,239]. Actinomycins [240,241], Bottromycins [41], and Telomycin [242-244].

\section{Different strategies for the development of new antibiotics from the genus Micromonospora.}

Understanding how the researchers identified antibiotics produced by Micromonospora strains in the past, and updating knowledge for the new analytical, biological and bioinformatics tools, can help to improve the strategy for the discovery of new chemical of antibiotic properties, which can reduce the cost and the time during biomolecule discovery.

Fig. 2 summarizes the complete biomolecule discovery platform of potential antimicrobial activity from the genus Micromonospora.

The isolation source is important for the isolation of new strains, which can produce new compounds. In the past, only cultured Micromonospora strains were used as source of antibiotics, but the developments of culture-independent methods increased the potential of novel molecule discovery. Using metabolomics-based tools can help for the early screening to identify new molecule. Utilization of genetic engineering, metabolomic pathways engineering, bioprocess development, and biotransformation techniques are widely applied not only to increase yields of production of secondary metabolites but also to lead to the synthesis of new more effective compounds. In addition, synthetic chemistry and structure modification methods are also important as component of the drug discovery platform in order to obtain a bioeffective final product approved by the regulatory authorities. 


\subsection{Natural habitat of Micromonospora and the research of new resources}

In general, soil is the main source for the isolation of Micromonospora producing antibiotics strains (Table 1). Also, they have been found to be constituents of endophytic actinobacterial populations recovered from plant tissues; they are a normal occupant of actinorhizal nodules [245]. In aquatic ecosystems (freshwater and marine environments), they were isolated from water samples, sediments, and aquatic organisms such as ascidians, sponges, soft coral and molluscs [246]. From the geographical point of view, from the data presented in Table 1, the highest numbers of Micromonospora producing antibiotics strains were isolated from Japan and United States. The 6 new species of Micromonospora discovered in 2014, was isolated from China, and one of them was isolated from Chinese black ant (Polyrhachis vicina Roger) [22-24,247-249]. Biogeographic studies of the distribution of bacterial strains producing secondary metabolites, are helpful for the selection of sampling coordinates [250]. For example, in the recent study of Charlop-Powers and his group was focused on the comparative biosynthetic gene richness and diversity of 96 soil microbiomes from different soil samples in USA. They used 454-pyroseqencing of non-ribosomal peptide adenylation (AD) and polyketide ketosynthase (KS) domain and concluded that the arid soils show the richest observed biosynthetic diversity, whereas brackish sediments and pine forest soils show the least [251].

\subsection{Culture depending approach}

The cultivation approach is still important in the screening for the discovery of new natural products. Different methods of sample pretreatment and medium formulation were used in the isolation and screening of Micromonospora species. Most of these methods use the resistance characteristic of Micromonospora spores as target [14,17,252,253]. For example, it was found that sample pretreatment at $65^{\circ} \mathrm{C}$ for $30 \mathrm{~min}$ is effective for the isolation of 
Micromonospora colonies from the estuarine sediments [254]. Bacteriophages were also applied in the screening of rare actinomycetes that can produce bioactive compounds [255]. The innovation of new isolation methods, can be useful for the cultivation of new Micromonospora strains, these include novel media formulation, new pretreatment protocols, and in situ cultivation strategy [256]. The best example is that of the isolation of the teixobactin producer strain Eleftheria terrae using new technique called isolation Chip Technique (iChip) [12].

\subsection{Culture-independent approach}

In the past, only cultured microorganisms were the source of natural product drug discovery, but the developments of culture-independent methods have allowed additional insights into the drug discovery research. Metagenomics is a reliable approach for the study of the micororganisms diversity, the measure of the potential reservoir of natural compounds and antibiotic resistance genes in the cultured and uncultured microbial population in the environment. In the same manner, meta-transcriptomics and meta-proteomics can also be used. The development of the next-generation deep sequencing, bio-informatics tools and available databases, represent a strong support to this line of research [257-262].

\subsection{Metabolomics-based approaches for secondary metabolite discovery}

Determination of the microbial metabolome is an important way for natural product discovery, and it is supported with the recent development of tools and methods that can detect and quantify metabolites [263-267]. The emerging of mass spectrometry techniques allowed the direct analysis of microbial colonies [268]. The matrix-assisted laser desorption/ionization mass spectrometry (MALDI-TOF MS) is used for the fast identification of bacterial and fungal microorganisms [269]. The MALDI-TOF MS was used before in 
characterization of some Micromonospora species [270]. The recent research has used this method for the rapid in situ detection of actinomycins in surface extracts of Streptomyces cells picked from agar plates [271]. Others promising methods of imaging mass spectrometry and real-time mass spectrometry will be also good tools for the identification of natural product from bacteria in the future [268], For example, Hsu et al. (2013), used ambient Electrospray Ionization Flow-Probe, to study in Real-Time metabolomics on living microorganisms $[268,272]$. On the other hand, the use mass spectrometry methods for microorganisms isolated from extreme environments may encountered some problems, like the database of MALDI TOF MS which need extension for reliable identification of bacteria from extreme environments [273]. For the best use of these methods for the identification and the early screening of Micromonospora strains, a comprehensive database of bioactive compounds should be available for comparison.

Others platforms such as Nuclear Magnetic Resonance (NMR), Gas ChromatographyMass Spectrometry (GC/MS), and Liquid Chromatography-Mass Spectrometry (LC/MS) are also useful in metabolomics study. Nowadays, LC/MS is the most widely used method in metabolomic analysis, due to its ability to separate and detect a wide range of molecules with high sensitivity [265,274]. Hou et al. [275] found a principal component analysis (PCA) using LC/MS is effective in the screening of marine bacterial strains of high metabolic activities and the detection of new products in drug discovery programs. Micromonolactam, produced by Micromonospora sp. CMS I1-30 and Micromonospora sp. CMS I2-32, was discovered during routine chemical screening (LC-DAD-ESIMS) of chemical fraction library of marine actinobacteria [276]. Recently, the secondary metabolites Neomacquarimicin, produced by Micromonospora sp. NPS2077, was identified during screening program for secondary metabolite with a polycyclic ring system from a bacterial species using LCMS/UV-based chemical analysis [277]. In addition, the metabolomics methods are adapted to 
be used in the high-throughput discovery metabolomics platforms. Thus, it is now possible to do mass spectrometric analysis of several hundred metabolites, with dense coverage of primary metabolism, in complex biological extracts and at throughputs of $>1000$ samples per day and the process can also be directed to specific target like enzyme activity $[278,279]$. The recent Advances in Infrared and Raman spectroscopy are also helpful in the rapid and low cost differentiation, identification and metabolome characterization of microbial strains [280,281]. Zhao et al. [282] studied FT-IR spectra of Micromonospora strains isolated from coastal sediments and found that this method can be applied to indicate in which environmental isolates have been cultured previously.

\subsection{Screening of biological activities}

It is essential before starting of any screening program of microorganisms for therapeutic metabolites production to select biological target. The classical screening methods were focused at first on antimicrobial activity (i.e. antibacterial, antifungal, anti-parasitic and antiviral). After the emergence and widespread of cancer and other new diseases, the current screening also include anticancer, cytotoxic, antioxidant and anti-inflammatory activities [246,283]. Nowadays, screening could include more specific target, for example: the antitumor antibiotics calicheamicins were discovered in a fermentation products screening program by the use of the biochemical induction assay (BIA), which utilized a genetically engineered strain of E. coli to detect DNA damaging agents [111]. MS-444, is naphtho[2,3-c] furan derivatives, Fig. 1(L), also exhibited myosin light-chain kinase inhibition activity (MLCK), without any antimicrobial effect [284,285]. This compound interfere with HuR RNA binding, HuR trafficking, cytokine expression and T-cell activation and showed good pharmacokinetics and low toxicity in mice [286]. Antascomicins, were obtained from a wide range screening program of more than 12,000 strains for selective isolation of macrophilin- 
binding metabolites. The most active strain was identified and given the name Micromonospora sp. A92-306401 and deposited in the German collection of microbes and cell culture under accession No. (DSMZ 8429). Antascomicins are structurally related to FK506, bind strongly to FKBP12 (also known as FKBPA1), but do not show immunosuppressive activity [287]. In addition, the presence of large therapeutic target databases is also helpful for the development of new biological assay [288]. Currently, with the development of High Throughput Screening (HTS) process, it is possible for concurrent screening of multiple biological activities of a large number of compounds [289].

\subsection{Genomic and metabolomic pathways engineering}

Determination of gene cluster required for the biosynthesis of certain metabolite can help to understand the possible biosynthetic pathways and thus used for the optimization of secondary metabolites production by metabolic engineering tools. The Gentamicin gene cluster was sequenced [43], it is a total of 32 ORFs have been assigned to the gentamicins gene cluster, 19-25 could encode biosynthetic enzyme functions, like gntK, a gene required for the methylation of purpurosamine C-6' in gentamicin biosynthesis $[42,44]$. The assigning functions to individual gene in gentamicin gene cluster, facilitated the study of diverse antibiotic biosynthesis pathways. Several biosynthetic pathways for gentamicin C complex production were proposed [43,44,290]. In 2014, Guo et al., gave information about late stage biosynthesis of gentamicins from the pseudo-disaccharideparomamine to the branch point at gentamicin X2, which was known substrate for C-methylation at C-6' to form G418 catalyzed by the radical SAM-dependent enzyme GenK, might instead undergo oxidation at C-6' to form an aldehyde, catalyzed by the flavin-linked dehydrogenase GenQ [290]. Recently, Huang et al. [291] identified four key enzymes that lead from the first-formed pseudotrisaccharide to gentamicin X2. These data can help for the optimization of secondary 
metabolites production. For example, to obtain a gentamicin $\mathrm{C} 1 \mathrm{a}-\mathrm{overproducing}$ strain, gacD gene was inactivated in $M$. echinospora. The inactivation of gacD blocks the metabolic pathways from X2 to G418 and leads to the accumulation of gentamicin C1a [292]. Through the use of combined traditional and recombinant genetic techniques it was possible to obtain strain with improved G418 production by 19 fold with minimal by product formation [293].

The function of cytochrome $\mathrm{P} 450$ enzyme-encoding genes $\operatorname{ros} C$ and $\operatorname{ros} D$ in the biosynthesis of rosamicin by $M$. rosaria was reported [294]. The production of rosamicin derivatives in $M$. rosaria was enhanced by the introduction of D-mycinose biosynthetic gene with PhiC31-derived integration vector pSET152 [295]. Recent research showed also that the introduction of d-mycinose biosynthesis genes in mycinamicin II biosynthesis gene cluster of M. guriseorubida A11725 into the rosC and rosD disrupted mutants of $M$. rosaria IFO13697 enhanced the production process. The resulting engineered strains, $M$. rosaria TPMA0054 and TPMA0069, produced mycinosyl rosamicin derivatives, IZIV and IZV, respectively. IZIV was identified as a novel mycinosyl rosamicin derivative, 23-O-mycinosyl-20-deoxo20-dihydrorosamicin [296]. By using genome scanning data of the hazimicin producer, $M$. echinospora ssp. challisensis NRRL 12255, it was possible to isolate TLN-05220, TLN05223, which have cytotoxic activities against various human tumor cell lines [217].

Others gene cluster and biosynthetic pathways of Micromonospora antibiotics have been reported, like the biosynthetic gene cluster of thiocoraline [297-299], evernimicin biosynthetic gene cluster from M. carbonacea var. africana ATCC39149 [143], mycinamycin gene cluster and biosyntheic pathway [300-303], and diazepinomicin biosynthetic pathway [304-306]. More recently, methionine gamma-lyase gene was identified in the calicheamicin biosynthesis gene cluster of M. echinospora [307].

\subsection{Bioprocess development and Biotransformation}


The aim of the bioprocess development is to increase yields of secondary metabolites production. Bioprocess is influenced by several factors, from the culture medium design (nutrients composition and concentrations), to cultivation parameters (temperature, $\mathrm{pH}$, agitation, aeration, etc...) [308-310]. Therefore, it is important to optimize all these parameters for maximal production yield using different approaches and also to transfer the process from small laboratory scale to pilot and large scale bioreactor level.

For example, gentamicin is manufactured through a complex process using Micromonospora strains. In general, the gentamicin is produced in submerged fermentation. The production medium optimization is an empirical process, as medium must be economic with high yield of production. Also it is important to use ingredients which help the downstream process [311]. Different Carbon sources were used in gentamicin production such as starch, sucrose, and soybean oil [312-316]. Nitrogen sources are important for cell growth and antibiotic production. Soybean meal, yeast extract, peptone and corn steep liquor have been reported as suitable substrates for gentamicin production [312,313,317,318]. Dipotassium phosphate $\left(\mathrm{K}_{2} \mathrm{HPO}_{4}\right)$ was usually the source of phosphate, and it is essential for the growth and antibiotic production [311]. It is apparent that cobalt is a requisite for the gentamicin synthesis. Charney et al. [312] found that medium must contain at least 0.01 $\mu \mathrm{g} / \mathrm{ml}$ of cobalt (as $\mathrm{CoCl}_{2} \cdot 6 \mathrm{H}_{2} \mathrm{O}$ ), which is equivalent to $2.5 \times 10^{-9}$ gram of cobalt per milliliter. In 2006, Himabindu et al. [315] used Response Surface Methodology (RSM) for the medium optimization to increase production of gentamicin by $M$. echinospora ATCC 15838. They found that a medium with Starch $(9 \mathrm{~g} / \mathrm{L})$, Soyabean meal $(3 \mathrm{~g} / \mathrm{L}), \mathrm{K}_{2} \mathrm{HPO}_{4}(0.9$ $\mathrm{g} / \mathrm{L})$ and $\mathrm{CoCl}_{2}(0.001 \mathrm{~g} / \mathrm{L})$, can give $880(\mathrm{mg} / \mathrm{L})$ of gentamicin. However, the problem of using complex medium components is seasonal variations and consistency of the chemical composition, which affect the yiled of the production process [311,319]. The $\mathrm{pH}$ of the culture medium can affect growth and gentamicin production in submerged cultures. Charney 
et al. [312], found that the optimal $\mathrm{pH}$ for production lies between 6.9 and 7.0. Other research conducted by Abou-zeid and Eissa [313] showed that the most suitable initial $\mathrm{pH}$ for antibiotic production was between 7 and 7.5. The dissolved oxygen (DO) is other critical limiting factor for both growth and gentamicin production. It was reported that gentamicin production reachs its maximal production when keeping the DO level at $40 \%$ saturation $[311,320]$. In addition, physiological status and size of the inoculum can also play critical role in gentamincin production process [311,321].

In general, gentamicin is usually produced as intracellular product. Different physical and chemical approaches were used to extract the antibiotic from the cells. Among them, ultrasonic treatment was the most efficient method in this process [317,322]. However, for large scale production, gentamycins are usually recovered by adsorption, solvent extraction, and crystallization [311]. One of the first reports of gentamicin purification was the work of Luedemann and Weinstein in 1963, in which they used cationic and anionic exchange adsorption column and methanol extraction in the purification process of gentamicin [323]. As gentamicin is a complex consisting of several minor and three major components, the proportions of these components can vary depending on the fermentation process, and some of the impurities can be also toxic $[311,324]$. Therefore, pharmaceutical industries are usually earger to develop more powerful methods of separation. In 2012, Grote et al. [324] described a method for synthesis of a single conjugate of gentamicin. They found that the reaction of the gentamicin complex with excess benzyl chloroformate provided a mixture of the amine protected components which can be separable by preparative HPLC using UV detection, which give opportunity to get a single gentamicin conjugate.

Gentamicin is administered intravenously, and the bactericidal activity is "concentrationdependent". Therefore, the dose used should be carefully adjusted. Also, gentamicin is not metabolized and eliminated by the kidneys and overdoses can increase the risks of renal 
toxicity and ototoxicity [325,326]. Routinely, in the pharmaceutical industry, and because of the chemical nature of the gentamicin complex, only the relative percentage of its major constituents are measured by liquid chromatography combined with pulsed electrochemical detection (LC-PED). Microbiological assays, immunoassays, and ELISA methods also can be used in gentamicin analysis [327]. Li et al. [328], reported a LC-PED method, with a reversed-phase C18 column and a mobile phase consisting of trifluoroacetic acid (TFA), pentafluoropropionic acid (PFPA), sodium hydroxide and acetonitrile, which showed better separation and more sensitive detection of the gentamicin components than the method using a polymer column. In the same time, Vucicevic-Prcetic et al. [327], developed a new analytical method for the determination of gentamicin based on Liquid Chromatography with tandem Mass Spectrometry (LC/MS/MS), which provides complete base line separation of components $\mathrm{C}_{1}, \mathrm{C}_{1 \mathrm{a}}, \mathrm{C}_{2}, \mathrm{C}_{2 \mathrm{a}}$ and $\mathrm{C}_{2} \mathrm{~b}$ according to the European and British Pharmacopoeias.

Biotransformation approach is also an efficient tool for the modification of existing antibiotic molecule to create new therapeutic agents. The addition of analogues of 2deoxystreptamine to mutant of $M$. inyoensis NRRL 3292, the sisomicin-producing organism, resulted in the formation of new antibiotics called Mutamicins [329]. Mutamicin 1, produced by the addition of streptamine to the fermentation broth, and Mutamicin 2 is produced by the addition of 2, 5-dideoxystreptamine [329]. Other research showed also that employing a recombinant Streptomyces venezuelae strain as a microbial catalyst, a reduced macrolide, 10, 11-dihydrorosamicin, was created from rosamicin macrolide. The new rosamicin analog showed 2-4-fold higher antibacterial activity against two strains of methicillin-resistant $S$. aureus compared to its parent rosamicin [330]. In the presence of serum, rustmicin rapidly epimerizes at the C-2 position and is converted to a $\gamma$-lactone, a product that is devoid of activity. In order to synthesize derivatives of Rustmicin with improved chemical stability and 
antifungal activity profiles, Shafiee et al. [331,332], used Streptomyces halstedii, in order to synthesize more stable compounds by the way of microbial hydroxylation.

\subsection{Synthetic chemistry and structure modification}

In many cases, it is difficult to use antibiotics with their original structure directly as therapeutic agents. This based on the development of antibiotic resistance strains, cytoxicity of the molecule, and improper pharmacokinetic and pharmacodynamics of the compound. For example, Gentamicin Cla can be used as a starting material for etimicin production, which is an antibiotic against drug-resistant bacteria and exhibit antimicrobial activity against both Gram-positive and Gram-negative bacteria [333,334]. Isepamicin is a semi-synthetic derivative of gentamicin $\mathrm{B}$, which possesses a high level of stability to aminoglycoside inactivating enzymes and low levels of toxicity to the kidney and inner ear. In addition, isepamicinis active against Gram-negative bacteria with resistance to amikacin and other aminoglycosides [335-337]. Netilmicin is a semisynthetic 1-N-ethyl derivative of sisomicin has similar activity as for gentamicin but less toxic [338]. Plazomicin, was synthetically derived from sisomicin by appending a hydroxy-aminobutyric acid substituent at position 1 and a hydroxyethyl substituent at position $6^{\prime}$. It is characterized by a dose-depending activity against both Gram-positive and Gram-negative pathogens [339-341]. In addition, derivative 6'-hydroxysisomicin, exhibits promising activity against a broad range of protozoan parasites [342]. Thiochoraline can be chemically synthesis [343,344], and different product were derivative from thiocoraline, like antitumor antibiotics NMe-azathiocoraline and Oxathiocoraline [345-347]. Already MS-444 and Rakicidin A have been also successfully chemically synthesized [171,348].

\section{Future perspectives}


The genus Micromonospora had been the source of many drugs, some of them, like gentamicin, are considered as essential to the global health medical system [46]. Although, there were some disappointments, despite the large number of papers and patents published, few number of bioactive molecules from this group of microorganisms reached the pharmaceutical market. In many cases, the drug development process was terminated at clinical trial level such as in case of evernimicin and rosaramicin [147]. However, new legislations and investments in biotechnology, can help the antibiotic development. In the last decade 11 new antibiotics were approved, and four in 2014 alone [9,349]. The biopharmaceutical industry need to be adapted to the global antibacterial drugs market, which is to reach an estimated value of $\$ 45.09$ billion in 2019 [350], and the current prescription data for aminoglycosides as antimicrobial represent over a $\$ 500$ million in U.S market. That is why, some biopharmaceutical companies start to acquire the intellectual property rights covering next-generation antibiotic derivatives, which retain the biologic activity, and appear less cytotoxic [350,351]. Also, reviving old antibiotics could be a good approach [352]. With the recent advances in screening program management, and the availability of more sophisticated analytical, biological and bioinformatics tools, the study of the genus Micromonospora is still important in the race of the discovery of new therapeutic agents. The investigation of new isolation sources and the use of innovative methods are good alternatives for the discovery of novel antibiotics from the genus Micromonospora.

\section{Declarations of interest}

The authors report no declarations of interest.

\section{References}


1. Donadio, S., S. Maffioli, P. Monciardini, M. Sosio, and D. Jabes (2010) Antibiotic discovery in the twenty-first century: current trends and future perspectives. J. Antibiot. 63: 423-430.

2. Vasoo, S., J. N. Barreto, and P. K. Tosh (2015) Emerging issues in gram-negative bacterial resistance: an update for the practicing clinician. Mayo. Clin. Proc. 90: 395403.

3. Hansen, M. P., T. C. Hoffmann, A. R. McCullough, M. L. van Driel, and C. B. Del Mar (2015) Antibiotic resistance: What are the opportunities for primary care in alleviating the crisis? Front. Public Health. 3: 35.

4. Siddique, H. (2014) Drug-resistant infections could lead to 10 million extra deaths a year - report. The guardian. http://www.theguardian.com/society/2014/dec/2011/drugresistant-infections-deaths-soar-2010m-by-2050-report.

5. O'Neil, J. (2014) Antimicrobial Resistance: Tackling a crisis for the health and wealth of nations. The Review on Antimicrobial Resistance. http://amr-review.org/.

6. Bérdy, J. (2012) Thoughts and facts about antibiotics: Where we are now and where we are heading. J. Antibiot. 65: 385-395.

7. Walsh, C. T. and T. A. Wencewicz (2013) Prospects for new antibiotics: a moleculecentered perspective. J. Antibiot. 67: 7-22.

8. Wright, G. (2015) An irresistible newcomer. Nature. 517: 442-444.

9. Doshi, P. (2015) Antibiotics Speeding new antibiotics to market: a fake fix? Bmj-Brit. Med. J. 350.

10. Demain, A. L. and S. Sanchez (2009) Microbial drug discovery: 80 years of progress. $J$. Antibiot. 62: 5-16.

11. Harvey, A. L., R. Edrada-Ebel, and R. J. Quinn (2015) The re-emergence of natural products for drug discovery in the genomics era. Nat. Rev. Drug. Discov. 14: 111-129. 
12. Ling, L. L., T. Schneider, A. J. Peoples, A. L. Spoering, I. Engels, B. P. Conlon, A. Mueller, T. F. Schaberle, D. E. Hughes, S. Epstein, M. Jones, L. Lazarides, V. A. Steadman, D. R. Cohen, C. R. Felix, K. A. Fetterman, W. P. Millett, A. G. Nitti, A. M. Zullo, C. Chen, and K. Lewis (2015) A new antibiotic kills pathogens without detectable resistance. Nature. 517: 455-459.

13. Tiwari, K. and R. K. Gupta (2012) Rare actinomycetes: a potential storehouse for novel antibiotics. Crit. Rev. Biotechnol. 32: 108-132.

14. Subramani, R. and W. Aalbersberg (2013) Culturable rare Actinomycetes: diversity, isolation and marine natural product discovery. Appl. Microbiol. Biotechnol. 97: 92919321.

15. Ørskov, J. (1923) Investigations into the morphology of the ray fungi. Levin and Munksgaard, Copenhagen, Denmark.

16. Genilloud, O. (2012) Genus Micromonospora. pp. 1039-1057. In: W. B. Whitman, M. Goodfellow, P. Kämpfer, H.-J. Busse, M. E. Trujillo, K.-I. Suzuki, and W. Ludwig (eds.). Bergey's Manual of Systematic Bacteriology - The Actinobacteria. Springer-Verlag, New York, USA.

17. Trujillo, M. E., K. Kui Hong, and O. Genilloud (2014) The Family Micromonosporaceae. pp. 499-569. In: E. Rosenberg, E. F. DeLong, S. L. Lor, E. Stackebrandt, and F. Thompson (eds.). The Prokaryotes - Actinobacteria. SpringerVerlag Berlin Heidelberg, Germany.

18. Foulerton, A. G. R. (1905) New species of Streptothrix isolated from the air. Lancet. $1199-1200$.

19. Erikson, D. (1941) Studies on some Lake-Mud strains of Micromonospora. J. Bacteriol. 41: $277-300$. 
20. Euzeby, J. P. (1997) List of bacterial names with standing in nomenclature: A folder available on the Internet. Int. J. Syst. Bacteriol. 47: 590-592.

21. Supong, K., C. Suriyachadkun, P. Pittayakhajonwut, K. Suwanborirux, and C. Thawai (2013) Micromonospora spongicola sp. nov., an actinomycete isolated from a marine sponge in the Gulf of Thailand. J. Antibiot. 66: 505-509.

22. Gao, R. X., C. X. Liu, J. W. Zhao, F. Y. Jia, C. Yu, L. Y. Yang, X. J. Wang, and W. S. Xiang (2014) Micromonospora jinlongensis sp. nov., isolated from muddy soil in China and emended description of the genus Micromonospora. Anton. Leeuw. Int. J. G. 105: $307-315$.

23. Shen, Y., Y. J. Zhang, C. X. Liu, X. J. Wang, J. W. Zhao, F. Y. Jia, L. Y. Yang, D. G. Yang, and W. S. Xiang (2014) Micromonospora zeae sp. nov., a novel endophytic actinomycete isolated from corn root (Zea mays L.). J. Antibiot. 67: 739-743.

24. Li, C., C. X. Liu, J. W. Zhao, Y. J. Zhang, R. X. Gao, X. H. Zhang, M. Yao, X. J. Wang, and W. S. Xiang (2014) Micromonospora maoerensis sp. nov., isolated from a Chinese pine forest soil. Anton. Leeuw. Int. J. G. 105: 451-459.

25. Thanaboripat, D., C. Thawai, C. Kittiwongwattana, C. Laosinwattana, P. Koohakan, and N. Parinthawong (2015) Micromonospora endophytica sp. nov., an endophytic actinobacteria of Thai upland rice (Oryza sativa). J. Antibiot. 68: 680-684.

26. Fang, B. Z., C. X. Liu, X. J. Guan, J. Song, J. W. Zhao, H. Liu, C. Li, W. X. Ning, X. J. Wang, and W. S. Xiang (2015) Two new species of the genus Micromonospora: Micromonospora palomenae sp. nov. and Micromonospora harpali sp. nov. isolated from the insects. Anton. Leeuw. Int. J. G. 108: 141-150.

27. Kittiwongwattana, C., D. Thanaboripat, C. Laosinwattana, P. Koohakan, N. Parinthawong, and C. Thawai (2015) Micromonospora oryzae sp. nov., isolated from roots of upland rice. Int. J. Syst. Evol. Microbiol. 65: 3818-3823. 
28. Jia, F. Y., C. X. Liu, S. Y. Zhou, J. S. Li, Y. Shen, X. J. Guan, S. Y. Guo, M. Y. Gao, X. J. Wang, and W. S. Xiang (2015) Micromonospora vulcania sp nov., isolated from volcanic sediment. Anton. Leeuw. Int. J. G. 108: 1383-1390.

29. Phongsopitanun, W., T. Kudo, M. Mori, K. Shiomi, P. Pittayakhajonwut, K. Suwanborirux, and S. Tanasupawat (2015) Micromonospora fluostatini sp. nov., isolated from marine sediment in Thailand. Int. J. Syst. Evol. Microbiol. 65: 4417-4423.

30. Lin, Y. B., M. C. Fan, Y. Q. Guo, X. H. Di, D. H. Dong, X. Zhang, and G. H. Wei (2015) Micromonospora nickelidurans sp. nov., isolated from nickel mining soil. Int. J. Syst. Evol. Microbiol. 65: 4615-4620

31. Zhang, L., L. Li, Z. Deng, and K. Hong (2015) Micromonospora zhanjiangensis sp. nov., isolated from mangrove forest. Int. J. Syst. Evol. Microbiol. 65: 4880-4885.

32. Waksman, S. A., W. B. Geiger, and E. Bugie (1947) Micromonosporin, an Antibiotic Substance from a Little-known Group of Microorganisms. J. Bacteriol. 53: 355-357.

33. Sato, S., F. Iwata, T. Fukae, and M. Katayama (2014) Neomacquarimicin: a new macquarimicin analog from marine-derived actinomycete. J. Antibiot. 67: 479-482.

34. Jana, S., and J. K. Deb (2005) Molecular targets for design of novel inhibitors to circumvent aminoglycoside resistance. Curr. drug targets. 6: 353-361.

35. Durante-Mangoni, E., A. Grammatikos, R. Utili, and M. E. Falagas (2009) Do we still need the aminoglycosides? Int. J. Antimicrob. Ag. 33: 201-205.

36. Dozzo, P. and H. E. Moser (2010) New aminoglycoside antibiotics. Expert. Opin. Ther. Pat. 20: 1321-1341.

37. Jackson, J., C. Chen, and K. Buising (2013) Aminoglycosides: how should we use them in the 21st century? Curr. Opin. Infect. Dis. 26: 516-525.

38. Poulikakos, P. and M. E. Falagas (2013) Aminoglycoside therapy in infectious diseases. Expert. Opin. Pharmaco. 14: 1585-1597. 
39. Fosso, M. Y., Y. J. Li, and S. Garneau-Tsodikova (2014) New trends in the use of aminoglycosides. Med. Chem. Comm. 5: 1075-1091.

40. Weinstein, M. J., G. M. Luedemann, E. M. Oden, G. H. Wagman, J. P. Rosselet, J. A. Marquez, C. T. Coniglio, W. Charney, H. L. Herzog, and J. Black (1963) Gentamicin,1 a new antibiotic complex from Micromonospora. J. Med. Chem. 6: 463-464.

41. Wagman, G. H. and M. J. Weinstein (1980) Antibiotic from Micromonospora. Annu. Rev. Microbiol. 34: 537-557.

42. Piepersberg, W., K. M. Aboshanab, H. Schmidt-Beißner, and U. F. Wehmeier (2007) The Biochemistry and Genetics of Aminoglycoside Producers. pp. 15-118. In: D. P. Arya (ed.). Aminoglycoside Antibiotics: From Chemical Biology to Drug Discovery. WileyInterscience, New Jersey, USA.

43. Unwin, J., S. Standage, D. Alexander, T. Hosted, A. C. Horan, and E. M. H. Wellington (2004) Gene cluster in Micromonospora echinospora ATCC15835 for the biosynthesis of the gentamicin C complex. J. Antibiot. 57: 436-445.

44. Hong, W. R. and L. B. Yan (2012) Identification of gntK, a gene required for the methylation of purpurosamine C-6 ' in gentamicin biosynthesis. J. Gen. Appl. Microbiol. 58: $349-356$.

45. Chen, C., Y. Chen, P. Wu, and B. Chen (2014) Update on new medicinal applications of gentamicin: Evidence-based review. J. Formos. Med. Assoc. 113: 72-82.

46. World Health Organization (2015) WHO Model List of Essential Medicines. http://www.who.int/medicines/publications/essentialmedicines/en/

47. Pichavant, C., A. Aartsma-Rus, P. R. Clemens, K. E. Davies, G. Dickson, S. Takeda, S. D. Wilton, J. A. Wolff, C. I. Wooddell, X. Xiao, and J. P. Tremblay (2011) Current status of pharmaceutical and genetic therapeutic approaches to treat DMD. Mol. Ther. 19: 830840. 
48. Stockwell, V. O. and B. Duffy (2012) Use of antibiotics in plant agriculture. Rev. Sci. Tech. Oie. 31: 199-210.

49. Wagman, G. H., R. T. Testa, J. A. Marquez, and M. J. Weinstein (1974) Antibiotic G-418, a new Micromonospora-produced aminoglycoside with activity against protozoa and helminths: fermentation, isolation, and preliminary characterization. Antimicrob. Agents Chemother. 6: 144-149.

50. Waitz, J. A., F. Sabatelli, F. Menzel, and E. L. Moss, Jr. (1974) Biological activity of antibiotic G-418, a new micromonospora-produced aminoglycoside with activity against protozoa and helminths. Antimicrob. Agents Chemother. 6: 579-581.

51. Rees, W. D. and S. M. Hay (1993) The expression of Escherichia-coli threonine synthase and the production of threonine from homoserine in mouse 3 t3 cells. Biochem. J. 291: $315-322$.

52. Ilavsky, J., A. P. Bayan, W. Charney, and H. Reimann (1975) Antibiotic from Micromonospora purpurea. US Patent 3903072.

53. Weinstein, M. J., G. M. Luedemann, G. H. Wagman, and J. A. Marquez (1969) Antibiotics 460 and methods for their production. US Patent 3454696.

54. Weinstein, M. J., J. A. Marquez, R. T. Testa, G. H. Wagman, E. M. Oden, and J. A. Waitz (1970) Antibiotic 6640, a new Micromonospora-produced aminoglycoside antibiotic. $J$. Antibiot. 23: 551-554.

55. Waitz, J. A., E. L. Moss, Jr., E. M. Oden, and M. J. Weinstein (1970) Antibiotic 6640. 3. Biological studies with antibiotic 6640, a new broad-spectrum aminoglycoside antibiotic. J. Antibiot. 23: 559-565.

56. Wagman, G. H., R. T. Testa, and J. A. Marquez (1970) Antibiotic 6640. II. Fermentation, isolation, and properties. J. Antibiot. 23: 555-558. 
57. Kondo, J., M. Koganei, and T. Kasahara (2012) Crystal structure and specific binding mode of sisomicin to the bacterial ribosomal decoding site. Acs. Med. Chem. Lett. 3: $741-744$.

58. Tansarli, G. S., P. I. Rafailidis, A. A. Papazoglou, and M. E. Falagas (2013) Antimicrobial activity and clinical effectiveness of sisomicin: an evaluation of the literature (1995-2011). Expert. Rev. Anti-Infe. 11: 421-428.

59. Marquez, J. A., G. H. Wagman, R. T. Testa, J. A. Waitz, and M. J. Weinstein (1976) A new broad spectrum aminoglycoside antibiotic, G-52, produced by Micromonospora zionensis. J. Antibiot. 29: 483-487.

60. Daniels, P. J., R. S. Jaret, T. L. Nagabhushan, and W. N. Turner (1976) The structure of antibiotic G-52, a new aminocyclitol-aminoglycoside antibiotic produced by Micromonospora zionensis. J. Antibiot. 29: 488-491.

61. Yu, P. K. and J. A. Washington (1974) Comparison of in vitro antibacterial activities of gentamicin and verdamicin. Antimicrob. Agents Chemother. 6: 526-528.

62. Weinstein, M. J., G. H. Wagman, J. A. Marquez, R. T. Testa, and J. A. Waitz (1975) Verdamicin, a new broad spectrum aminoglycoside antibiotic. Antimicrob. Agents Chemother. 7: 246-249.

63. Okachi, R., I. Kawamoto, S. Takasawa, M. Yamamoto, and S. Sato (1974) A new antibiotic XK-62-2 (Sagamicin). I. Isolation, physicochemical and antibacterial properties. J. Antibiot. 27: 793-800.

64. Nara, T., I. Kawamoto, R. Okachi, S. Takasawa, and M. Yamamoto (1975) New antibiotic XK-62-2 (sagamicin). II Taxonomy of the producing organism, fermentative production and characterization of sagamicin. J. Antibiot. 28: 21-28.

65. Marone, P., V. Monzillo, E. Carretto, E. Haeusler, and E. Antoniazzi (2002) In vitro activity of sagamicin against ocular bacterial isolates. Ophthalmologica. 216: 133-138. 
66. Nara, T., M. Yamamoto, I. Kawamoto, K. Takayama, R. Okachi, S. Takasawa, T. Sato, and S. Sato (1977) Fortimicins A and B, new aminoglycoside antibiotics. I. Producing organism, fermentation and biological properties of fortimicins. J. Antibiot. 30: 533-540.

67. Egan, R. S., R. S. Stanaszek, M. Cirovic, S. L. Mueller, J. Tadanier, J. R. Martin, P. Collum, A. W. Goldstein, R. L. De Vault, A. C. Sinclair, E. E. Fager, and L. A. Mitscher (1977) Fortimicins A and B, new aminoglycoside antibiotics. III. Structural identification. J. Antibiot. 30: 552-563.

68. Okachi, R., S. Takasawa, T. Sato, S. Sato, M. Yamamoto, I. Kawamoto, and T. Nara (1977) Fortimicins A and B, new aminoglycoside antibiotics. II. Isolation, physicochemical and chromatographic properties. J. Antibiot. 30: 541-551.

69. Sugimoto, M., S. Ishii, R. Okachi, and T. Nara (1979) Fortimicins C, D and KE, new aminoglycoside antibiotics. J. Antibiot. 32: 868-873.

70. Iida, T., M. Sato, I. Matsubara, Y. Mori, and K. Shirahata (1979) The structures of fortimicins C, D, and KE. J. Antibiot. 32: 1273-1279.

71. Girolami, R. L., and J. M. Stamm (1977) Fortimicins A and B, new aminoglycoside antibiotics. IV. In vitro study of fortimicin A compared with other aminoglycosides. $J$. Antibiot. 30: 564-570.

72. Moreau, N., C. Jaxel, and F. Le Goffic (1984) Comparison of fortimicins with other aminoglycosides and effects on bacterial ribosome and protein synthesis. Antimicrob. Agents Chemother. 26: 857-862.

73. Kobinata, K., M. Uramoto, T. Mizuno, and K. Isono (1980) A new antibiotic, antlermicin A. J. Antibiot. 33: 244-246.

74. Kobinata, K., M. Uramoto, T. Mizuno, and K. Isono (1980) Antlermicins B and C, new members of the antlermicin family. J. Antibiot. 33: 772-775. 
75. Tomita, F., T. Tamaoki, K. Shirahata, M. Kasai, M. Morimoto, S. Ohkubo, K. Mineura, and S. Ishii (1980) Novel antitumor antibiotics, tetrocarcins. J. Antibiot. 33: 668-670.

76. Tomita, F. and T. Tamaoki (1980) Tetrocarcins, novel antitumor antibiotics. I. Producing organism, fermentation and antimicrobial activity. J. Antibiot. 33: 940-945.

77. Tamaoki, T., M. Kasai, K. Shirahata, and F. Tomita (1982) Tetrocarcins E1, E2, F and F1, new antibiotics. Fermentation, isolation and characterization. J. Antibiot. 35: 979-984.

78. Tamaoki, T., M. Kasai, K. Shirahata, S. Ohkubo, M. Morimoto, K. Mineura, S. Ishii, and F. Tomita (1980) Tetrocarcins, novel antitumor antibiotics. II. Isolation, characterization and antitumor activity. J. Antibiot. 33: 946-950.

79. Morimoto, M., M. Fukui, S. Ohkubo, T. Tamaoki, and F. Tomita (1982) Tetrocarcins, new antitumor antibiotics. 3. Antitumor activity of tetrocarcin A. J. Antibiot. 35: 10331037.

80. Oka, Y., H. Ishida, M. Morioka, Y. Numasaki, T. Yamafuji, T. Osono, and H. Umezawa (1981) Combimicins, new kanamycin derivatives bioconverted by some Micromonosporas. J. Antibiot. 34: 777-781.

81. Shimotohno, K. W., T. Endo, and K. Furihata (1993) Antibiotic AC6H, a new component of tetrocarcin group antibiotics. J. Antibiot. 46: 682-686.

82. Sadarangani, S. P., L. L. Estes, and J. M. Steckelberg (2015) Non-anti-infective effects of antimicrobials and their clinical applications: A Review. Mayo. Clin. Proc. 90: 109-127.

83. Mallams, A. K. (1969) The megalomicins. I. D-rhodosamine, a new dimethylamino sugar. J. Am. Chem. Soc. 91: 7505-7506.

84. Mallams, A. K., R. S. Jaret, and H. Reimann (1969) The megalomicins. II. The structure of megalomicin A. J. Am. Chem. Soc. 91: 7506-7508.

85. Jaret, R. S., A. K. Mallams, and H. Reimann (1973) The megalomicins. IV. The structures of megalomicins A, B, C1, and C2. J. Chem. Soc. [Perkin 1]. 13: 1374-1388. 
86. Jaret, R. S., A. K. Mallams, and H. F. Vernay (1973) The megalomicins. V. Mass spectral studies. J. Chem. Soc. [Perkin 1]. 13: 1389-1400.

87. Mallams, A. K. (1973) The megalomicins. 3. D-Rhodosamine, a new dimethylaminosugar. J. Chem. Soc. [Perkin 1]. 13: 1369-1374.

88. Wagman, G. H., J. A. Waitz, J. Marquez, A. Murawaski, E. M. Oden, R. T. Testa, and M. J. Weinstein (1972) A new Micromonospora-produced macrolide antibiotic, rosamicin. $J$. Antibiot. 25: 641-646.

89. Waitz, J. A., C. G. Drube, E. L. Moss, Jr., and M. J. Weinstein (1972) Biological studies with rosamicin, a new Micromonospora-produced macrolide antibiotic. J. Antibiot. 25: $647-652$.

90. Ganguly, A. K., B. K. Lee, R. Brambilla, R. Condon, and O. Sarre (1976) Biosynthesis of rosamicin. J. Antibiot. 29: 976-977.

91. Puar, M. S. and D. Schumacher (1990) Novel Macrolides from Micromonospora rosaria. J. Antibiot. 43: 1497-1501.

92. Crowe, C. C. and W. E. Sanders, Jr. (1974) Rosamicin: evaluation in vitro and comparison with erythromycin and lincomycin. Antimicrob. Agents Chemother. 5: 272275.

93. Santoro, J., D. Kaye, and M. E. Levison (1976) In vitro activity of josamycin and rosamicin against Bacteroides fragilis compared with clindamycin, erythromycin, and metronidazole. Antimicrob. Agents Chemother. 10: 188-190.

94. Hatano, K., E. Higashide, and M. Shibata (1976) Studies on juvenimicin, a new antibiotic. I. Taxonomy, fermentation and antimicrobial properties. J. Antibiot. 29: 11631170. 
95. Kishi, T., S. Harada, H. Yamana, and A. Miyake (1976) Studies on juvenimicin, a new antibiotic. II. Isolation, chemical characterization and structures. J. Antibiot. 29: 11711181

96. Carlson, S., L. Marler, S.-J. Nam, B. Santarsiero, J. Pezzuto, and B. Murphy (2013) Potential chemopreventive activity of a new macrolide antibiotic from a Marine-Derived Micromonospora sp. Marine Drugs. 11: 1152-1161.

97. Satoi, S., N. Muto, M. Hayashi, T. Fujii, and M. Otani (1980) Mycinamicins, new macrolide antibiotics. I. Taxonomy, production, isolation, characterization and properties. J. Antibiot. 33: 364-376.

98. Hayashi, M., H. Ohara, M. Ohno, H. Sakakibara, S. Satoi, K. I. Harada, and M. Suzuki (1981) Mycinamicins, new macrolide antibiotics. V. Isolation and structures of new 16membered aglycones, mycinolide IV and protomycinolide IV. J. Antibiot. 34: 10751077.

99. Hayashi, M., M. Ohno, K. Kinoshita, S. Satoi, M. Suzuki, and K. Harada (1981) Mycinamicins, new macrolide antibiotics. III Isolation and structures of mycinamicin aglycones, mycinolide IV and V. J. Antibiot. 34: 346-349.

100.Hayashi, M., M. Ohno, S. Katsumata, S. Satoi, K. Harada, M. Takeda, and M. Suzuki (1981) Mycinamicins, new macrolide antibiotics. IV. Structure of mycinamicin III. J. Antibiot. 34: 276-281.

101.Hayashi, M., K. Kinoshita, S. Satoi, and K. Nakatsu (1982) Mycinamicins, new macrolide antibiotics. VI. X-ray crystallography of mycinolide IV. J. Antibiot. 35: 12431244.

102.Hayashi, M., K. Kinoshita, Y. Sudate, S. Satoi, H. Sakakibara, K. Harada, and M. Suzuki (1983) Mycinamicins, new macrolide antibiotics. VII. Structures of minor components, mycinamicin VI and VII. J. Antibiot. 36: 175-178. 
103.Harada, K., N. Takeda, M. Suzuki, M. Hayashi, M. Ohno, and S. Satoi (1985) Mycinamicins, new macrolide antibiotics. IX. Chemical ionization mass spectral studies on mycinamicins. J. Antibiot. 38: 868-876.

104.Kinoshita, K., S. Satoi, M. Hayashi, K. Harada, M. Suzuki, and K. Nakatsu (1985) Mycinamicins, new macrolide antibiotics. VIII. Chemical degradation and absolute configuration of mycinamicins. J. Antibiot. 38: 522-526.

105.Kinoshita, K., Y. Imura, S. Takenaka, and M. Hayashi (1989) Mycinamicins, new macrolide antibiotics. XI. Isolation and structure elucidation of a key intermediate in the biosynthesis of the mycinamicins, mycinamicin VIII. J. Antibiot. 42: 1869-1872.

106.Kinoshita, K., S. Satoi, M. Hayashi, and K. Nakatsu (1989) Mycinamicins, new macrolide antibiotics. X. X-ray crystallography and the absolute configuration of mycinamicin IV. J. Antibiot. 42: 1003-1005.

107.Kinoshita, K., S. Takenaka, and M. Hayashi (1991) Mycinamicins, new macrolide antibiotics .12. Isolation and structural elucidation of Mycinamicin-X and MycinamicinXi. J. Antibiot. 44: 1270-1273.

108.Kinoshita, K., S. Takenaka, H. Suzuki, T. Morohoshi, and M. Hayashi (1992) Mycinamicins, New Macrolide Antibiotics .13. Isolation and structures of novel fermentation products from Micromonospora griseorubida (Ferm Bp-705). J. Antibiot. 45: 1-9.

109.Kinoshita, K., S. Takenaka, H. Suzuki, T. Morohoshi, and M. Hayashi (1992) Mycinamicins, new macrolide antibiotics. XIII. Isolation and structures of novel fermentation products from Micromonospora griseorubida (FERM BP-705). J. Antibiot. 45: 1-9.

110.Maiese, W. M., M. P. Lechevalier, H. A. Lechevalier, J. Korshalla, N. Kuck, A. Fantini, M. J. Wildey, J. Thomas, and M. Greenstein (1989) Calicheamicins, a novel family of 
antitumor antibiotics: taxonomy, fermentation and biological properties. J. Antibiot. 42: $558-563$.

111.Lee, M. D., J. K. Manning, D. R. Williams, N. A. Kuck, R. T. Testa, and D. B. Borders (1989) Calicheamicins, a novel family of antitumor antibiotics. 3. Isolation, purification and characterization of calicheamicins beta $1 \mathrm{Br}$, gamma $1 \mathrm{Br}$, alpha 2I, alpha 3I, beta $1 \mathrm{I}$, gamma 1I and delta 1I. J. Antibiot. 42: 1070-1087.

112.Lee, M. D., G. A. Ellestad, and D. B. Borders (1991) Calicheamicins - Discovery, Structure, Chemistry, and Interaction with DNA. Accounts. Chem. Res. 24: 235-243.

113.Hinman, L. M., P. R. Hamann, R. Wallace, A. T. Menendez, F. E. Durr, and J. Upeslacis (1993) Preparation and characterization of monoclonal antibody conjugates of the calicheamicins: a novel and potent family of antitumor antibiotics. Cancer Res. 53: $3336-3342$.

114.Sorokin, P. (2000) Mylotarg approved for patients with CD33+ acute myeloid leukemia. Clin. J. Oncol. Nurs. 4: 279-280.

115.Jefferson, E. (2010) FDA: Pfizer voluntarily withdraws cancer treatment Mylotarg from U.S. Market. U.S. Food and Drug Administration. http://www.fda.gov/NewsEvents/Newsroom/PressAnnouncements/2010/ucm216448.htm

116.Venditto, V. J. and F. C. Szoka (2013) Cancer nanomedicines: So many papers and so few drugs! Adv. Drug Deliv. Rev. 65: 80-88.

117.Loke, J., J. N. Khan, J. S. Wilson, C. Craddock, and K. Wheatley (2014) Mylotarg has potent anti-leukaemic effect: a systematic review and meta-analysis of anti-CD33 antibody treatment in acute myeloid leukaemia. Ann. Hematol. 94: 361-373.

118.Liu, W. C., G. Astle, J. S. Wells, Jr., W. H. Trejo, P. A. Principe, M. L. Rathnum, W. L. Parker, O. R. Kocy, and R. B. Sykes (1980) Izumenolide-a novel beta-lactamase inhibitor 
produced by Micromonospora. I. Detection, isolation and characterization. J. Antibiot. 33: $1256-1261$.

119.Bush, K., D. P. Bonner, and R. B. Sykes (1980) Izumenolide-a novel beta-lactamase inhibitor produced by Micromonospora. II. Biological properties. J. Antibiot. 33: 12621269.

120.Bush, K., J. Freudenberger, and R. B. Sykes (1980) Inhibition of Escherichia coli TEM-2 beta-lactamase by the sulfated compounds izumenolide, panosialin and sodium dodecyl sulfate. J. Antibiot. 33: 1560-1562.

121.Mantoku, A. and H. Ogawara (1981) Interaction of beta-lactamase of Streptomyces cacaoi. II. CP-45,899, izumenolide and cephamycins. J. Antibiot. 34: 1347-1350.

122.Ikeda, Y., S. Kando, T. Sawa, M. Tsuchiya, D. Ikeda, M. Hamada, T. Takeuchi, and H. Umezawa (1981) Dotriacolide, a new beta-lactamase inhibitor. J. Antibiot. 34: 16281630.

123.Takenaka, S., K. Yoshida, O. Yamaguchi, K. Shimizu, T. Morohoshi, and K. Kinoshita (1998) Enhancement of mycinamicin production by dotriacolide in Micromonospora griseorubida. FEMS Microbiol. Lett. 167: 95-100.

124.Takatsu, T., H. Nakayama, A. Shimazu, K. Furihata, K. Ikeda, K. Furihata, H. Seto, and N. Otake (1985) Rustmicin, a new macrolide antibiotic active against wheat stem rust fungus. J. Antibiot. 38: 1806-1809.

125.Nakayama, H., T. Takatsu, Y. Abe, A. Shimazu, K. Furihata, K. Ikeda, K. Furihata, H. Seto, and N. Ōtake (1987) Rustmicin, a new macrolide antibiotic active against wheat stem rust fungus. Agric. Biol. Chem. 51: 853-859

126.Omura, S., N. Imamura, R. Oiwa, H. Kuga, R. Iwata, R. Masuma, and Y. Iwai (1986) Clostomicins, new antibiotics produced by Micromonospora echinospora subsp. 
armeniaca subsp. nov. I. Production, isolation, and physico-chemical and biological properties. J. Antibiot. 39: 1407-1412.

127.Takahashi, Y., Y. Iwai, and S. Omura (1986) Clostomicins, new antibiotics produced by Micromonospora echinospora subsp. armeniaca subsp. nov. II. Taxonomic study of the producing microorganism. J. Antibiot. 39: 1413-1418.

128.Hayakawa, Y., M. Matsuoka, K. Shinya, and H. Seto (1993) Quinolidomicins a(1), a(2) and $\mathrm{B}(1)$, Novel 60-membered macrolide antibiotics .1. Taxonomy, fermentation, isolation, physicochemical properties and biological-activity. J. Antibiot. 46: 1557-1562.

129.Hayakawa, Y., K. Shinya, K. Furihata, and H. Seto (1993) Quinolidomicins a(1), a(2) and B(1), novel 60-membered macrolide antibiotics .2. Structure elucidation. J. Antibiot. 46: $1563-1569$.

130.Lam, K. S., G. A. Hesler, D. R. Gustavson, R. L. Berry, K. Tomita, J. L. MacBeth, J. Ross, D. Miller, and S. Forenza (1996) Pyrrolosporin A, a new antitumor antibiotic from Micromonospora sp. C39217-R109-7 .1. Taxonomy of producing organism, fermentation and biological activity. J. Antibiot. 49: 860-864.

131.Schroeder, D. R., K. L. Colson, S. E. Klohr, M. S. Lee, J. A. Matson, L. S. Brinen, and J. Clardy (1996) Pyrrolosporin A, a new antitumor antibiotic from Micromonospora sp. C39217-R109-7 .2. Isolation, physico-chemical properties, spectroscopic study and Xray analysis. J. Antibiot. 49: 865-872.

132.Vieweg, L., S. Reichau, R. Schobert, P. F. Leadlay, and R. D. Sussmuth (2014) Recent advances in the field of bioactive tetronates. Nat. Prod. Rep. 31: 1554-1584.

133.Fehr, T., V. F. J. Quesniaux, J. J. Sanglier, L. Oberer, L. Gschwind, M. Ponelle, W. Schilling, S. Wehrli, A. Enz, G. Zenke, and W. Schuler (1997) Cymbimicin A and B, two novel cyclophilin-binding structures isolated from actinomycetes. J. Antibiot. 50: 893899. 
134.Canedo, L. M., J. L. F. Puentes, J. P. Baz, X. H. Huang, and K. L. Rinehart (2000) IB96212, a novel cytotoxic macrolide produced by a marine Micromonospora - II. Physicochemical properties and structure determination. J. Antibiot. 53: 479-483.

135.Fernandez-Chimeno, R. I., L. Canedo, F. Espliego, D. Gravalos, F. De la Calle, J. L. Fernandez-Puentes, and F. Romero (2000) IB-96212, a novel cytotoxic macrolide produced by a marine Micromonospora - I. Taxonomy, fermentation, isolation and biological activities. J. Antibiot. 53: 474-478.

136.Igarashi, Y., K. Takagi, Y. Kan, K. Fujii, K. Harada, T. Furumai, and T. Oki (2000) Arisostatins $\mathrm{A}$ and $\mathrm{B}$, new members of tetrocarcin class of antibiotics from Micromonospora sp. TP-A0316 - II. Structure determination. J. Antibiot. 53: 233-240.

137.Furumai, T., K. Takagi, Y. Igarashi, N. Saito, and T. Oki (2000) Arisostatins A and B, new members of tetrocarcin class of antibiotics from Micromonospora sp. TP-A0316 - I. Taxonomy, fermentation, isolation and biological properties. J. Antibiot. 53: 227-232.

138.Kim, Y. H., H. C. Shin, D. W. Song, S. H. Lee, T. Furumai, J. W. Park, and T. K. Kwon (2003) Arisostatins A induces apoptosis through the activation of caspase-3 and reactive oxygen species generation in AMC-HN-4 cells. Biochem. Biophys. Res. Commun. 309: $449-456$.

139.Thawai, C., P. Kittakoop, S. Tanasupawat, K. Suwanborirux, K. Sriklung, and Y. Thebtaranonth (2004) Micromonosporin A, a novel 24-membered polyene lactam macrolide from Micromonospora sp. isolated from peat swamp forest. Chem. Biodivers. 1: 640-645.

140.Peng, F., C. X. Wang, Y. Xie, H. L. Jiang, L. J. Chen, P. Uribe, A. T. Bull, M. Goodfellow, H. Jiang, and Y. Y. Lian (2013) A new 20-membered macrolide produced by a marine-derived Micromonospora strain. Nat. Prod. Res. 27: 1366-1371. 
141.Weinstein, M. J., G. M. Luedemann, E. M. Oden, and G. H. Wagman (1964) Everninomicin, a new antibiotic complex from Micromonospora carbonacea. Antimicrob. Agents Chemother. 10: 24-32.

142.Herzog, H. L., E. Meseck, S. Delorenzo, A. Murawski, W. Charney, and J. P. Rosselet (1965) Chemistry of antibiotics from Micromonospora. 3. Isolation and characterization of Everninomicin D and B. Appl. Microbiol. 13: 515-520.

143.Hosted, T. J., T. X. Wang, D. C. Alexander, and A. C. Horan (2001) Characterization of the biosynthetic gene cluster for the oligosaccharide antibiotic, Evernimicin, in Micromonospora carbonacea var. africana ATCC39149. J. Ind. Microbiol. Biot. 27: $386-392$.

144.Sanders, W. E., Jr., and C. C. Sanders (1974) Microbiological characterization of everninomicins B and D. Antimicrob. Agents Chemother. 6: 232-238.

145.Jones, R. N., R. S. Hare, F. J. Sabatelli, and Z. S. T. Grp (2001) In vitro Gram-positive antimicrobial activity of evernimicin (SCH 27899), a novel oligosaccharide, compared with other antimicrobials: a multicentre international trial. J. Antimicrob. Chemoth. 47: $15-25$.

146.Belanger, A. E. and T. R. Shryock (2005) Avilamycin did not play a role in the discontinuation of evernimicin as a clinical drug candidate. J. Mass Spectrom. 40: 11091109.

147.Ganguly, A. K. (2013) Chapter One - Challenges in drug discovery at Schering-Plough research institute: A personal reflection. pp. 3-14. In: M. C. Desai (ed.). Annual Reports in Medicinal Chemistry - Volume 48, Academic Press, San Diego, USA.

148.Ando, O., H. Satake, K. Itoi, A. Sato, M. Nakajima, S. Takahashi, H. Haruyama, Y. Ohkuma, T. Kinoshita, and R. Enokita (1991) Trehazolin, a new trehalase inhibitor. $J$. Antibiot. 44: 1165-1168. 
149.Ando, O., M. Nakajima, K. Hamano, K. Itoi, S. Takahashi, Y. Takamatsu, A. Sato, R. Enokita, T. Okazaki, H. Haruyama, and et al. (1993) Isolation of trehalamine, the aglycon of trehazolin, from microbial broths and characterization of trehazolin related compounds. J. Antibiot. 46: 1116-1125.

150.Weinstein, M. J., G. M. Luedemann, E. M. Oden, and G. H. Wagman (1967) Halomicin, a new Micromonospora-produced antibiotic. Antimicrob. Agents Chemother. 7: 435-441.

151.Ganguly, A. K., Y. T. Liu, O. Z. Sarre, and S. Szmulewicz (1977) Structures of halomicins A and C. J. Antibiot. 30: 625-627.

152.Maiese, W. M., M. P. Lechevalier, H. A. Lechevalier, J. Korshalla, J. Goodman, M. J. Wildey, N. Kuck, and M. Greenstein (1989) LL-E19085 alpha, a novel antibiotic from Micromonospora citrea : taxonomy, fermentation and biological activity. J. Antibiot. 42: $846-851$.

153.Carter, G. T., J. A. Nietsche, D. R. Williams, and D. B. Borders (1990) Citreamicins, novel antibiotics from Micromonospora citrea: isolation, characterization, and structure determination. J. Antibiot. 43: 504-512.

154.Puar, M. S., T. M. Chan, V. Hegde, M. Patel, P. Bartner, K. J. Ng, B. N. Pramanik, and R. D. MacFarlane (1998) Sch 40832: A novel thiostrepton from Micromonospora carbonacea. J. Antibiot. 51: 221-224.

155.Bagley, M. C., J. W. Dale, E. A. Merritt, and A. Xiong (2005) Thiopeptide antibiotics. Chem. Rev. 105: 685-714.

156.Just-Baringo, X., F. Albericio, and M. Alvarez (2014) Thiopeptide antibiotics: Retrospective and recent advances. Marine Drugs. 12: 317-351.

157.Shoji, J., H. Hinoo, T. Kato, K. Nakauchi, S. Matsuura, M. Mayama, Y. Yasuda, and Y. Kawamura (1981) Isolation of N-(2,6-diamino-6-hydroxymethylpimelyl)-L-alanine from Micromonospora chalcea. J. Antibiot. 34: 374-380. 
158.Kawamura, Y., Y. Yasuda, and M. Mayama (1981) Isolation of L-2-(1methylcyclopropyl)glycine from Micromonospora miyakonensis sp. nov. I. Taxonomic studies on the producing microorganism. J. Antibiot. 34: 367-373.

159.Shoji, J., R. Sakazaki, T. Kato, K. Tori, Y. Yoshimura, and S. Matsuura (1981) Isolation of L-2-(1-methylcyclopropyl)glycine from Micromonospora miyakonensis sp. nov. II. Isolation and characterization. J. Antibiot. 34: 370-373.

160.Kase, H., M. Kaneko, and K. Yamada (1987) K-13, a novel inhibitor of angiotensin I converting enzyme produced by Micromonospora halophytica subsp. exilisia. I. Fermentation, isolation and biological properties. J. Antibiot. 40: 450-454.

161.Yasuzawa, T., K. Shirahata, and H. Sano (1987) K-13, a novel inhibitor of angiotensin I converting enzyme produced by Micromonospora halophytica subsp. exilisia. II. Structure determination. J. Antibiot. 40: 455-458.

162.Cooper, R., A. C. Horan, F. Gentile, V. Gullo, D. Loebenberg, J. Marquez, M. Patel, M. S. Puar, and I. Truumees (1988) Sch 37137, a novel antifungal compound produced by a Micromonospora sp. Taxonomy, fermentation, isolation, structure and biological properties. J. Antibiot. 41: 13-19.

163.Lam, K. S., D. R. Gustavson, G. A. Hesler, T. T. Dabrah, J. E. Matson, R. L. Berry, W. C. Rose, and S. Forenza (1995) Korkormicins, novel depsipeptide antitumor antibiotics from Micromonospora sp. C39500 - Fermentation, precursor directed biosynthesis and biological-activities. J. Ind. Microbiol. 15: 60-65.

164.Janin, Y. L. (2003) Peptides with anticancer use or potential. Amino Acids. 25: 1-40.

165.Kitagaki, J. and Y. L. Yang (2011) DNA intercalator korkormicin A preferentially kills tumor cells expressing wild type p53. Biochem. Bioph. Res. Co. 414: 186-191.

166.Kitagaki, J., G. B. Shi, S. Miyauchi, S. Murakami, and Y. L. Yang (2015) Cyclic depsipeptides as potential cancer therapeutics. Anti-cancer Drugs. 26: 259-271. 
167.McBrien, K. D., R. L. Berry, S. E. Lowe, K. M. Neddermann, I. Bursuker, S. Huang, S. E. Klohr, and J. E. Leet (1995) Rakicidins, new cytotoxic lipopeptides from Micromonospora sp. Fermentation, isolation and characterization. J. Antibiot. 48: 14461452.

168. Yamazaki, Y., S. Kunimoto, and D. Ikeda (2007) Rakicidin A: A hypoxia-selective cytotoxin. Biol. Pharm. Bull. 30: 261-265.

169. Takeuchi, M., E. Ashihara, Y. Yamazaki, S. Kimura, Y. Nakagawa, R. Tanaka, H. Yao, R. Nagao, Y. Hayashi, H. Hirai, and T. Maekawa (2011) Rakicidin A effectively induces apoptosis in hypoxia adapted Bcr-Abl positive leukemic cells. Cancer Sci. 102: 591-596.

170.Oku, N., S. Matoba, Y. M. Yamazaki, R. Shimasaki, S. Miyanaga, and Y. Igarashi (2014) Complete Stereochemistry and preliminary structure-activity relationship of Rakicidin A, a hypoxia-selective cytotoxin from Micromonospora sp. J. Nat. Prod. 77: 2561-2565.

171.Sang, F., D. M. Li, X. L. Sun, X. Q. Cao, L. Wang, J. L. Sun, B. X. Sun, L. L. Wu, G. Yang, X. Q. Chu, J. H. Wang, C. M. Dong, Y. Geng, H. Jiang, H. B. Long, S. J. Chen, G. Y. Wang, S. Z. Zhang, Q. Zhang, and Y. Chen (2014) Total synthesis and determination of the absolute configuration of Rakicidin A. J. Am. Chem. Soc. 136: 15787-15791.

172.Baz, J. P., L. M. Canedo, J. L. F. Puentes, and M. V. S. Elipe (1997) Thiocoraline, a novel depsipeptide with antitumor activity produced by a marine Micromonospora .2. Physicochemical properties and structure determination. J. Antibiot. 50: 738-741.

173.Romero, F., F. Espliego, J. P. Baz, T. G. DeQuesada, D. Gravalos, F. DelaCalle, and J. L. FernadezPuertes (1997) Thiocoraline, a new depsipeptide with antitumor activity produced by a marine Micromonospora .1. Taxonomy, fermentation, isolation, and biological activities. J. Antibiot. 50: 734-737.

174.Blunt, J. W., B. R. Copp, W. P. Hu, M. H. G. Munro, P. T. Northcote, and M. R. Prinsep (2008) Marine natural products. Nat. Prod. Rep. 25: 35-94. 
175.Avan, I., C. D. Hall, and A. R. Katritzky (2014) Peptidomimetics via modifications of amino acids and peptide bonds. Chem. Soc. Rev. 43: 3575-3594.

176.Erba, E., D. Bergamaschi, S. Ronzoni, M. Faretta, L. Bassano, F. Vikhanskaya, J. Jimeno, G. Faircloth, C. V. Catapano, and M. D'Incalci (1998) Thiocoraline, a novel DNA polymerase inhibitor with a higher cytotoxic potency against cancer cells with mutated or inactivated p53. Ann. Oncol. 9: 141-141.

177.Erba, E., D. Bergamaschi, S. Ronzoni, M. Faretta, S. Taverna, M. Bonfanti, C. V. Catapano, G. Faircloth, J. Jimeno, and M. D'Incalci (1999) Mode of action of thiocoraline, a natural marine compound with anti-tumour activity. Brit. J. Cancer. 80: 971-980.

178.Wyche, T. P., R. Jaskula-Sztul, A. Dammalapati, H. Cho, G. Kwon, H. Chen, and T. S. Bugni (2012) Thiocoraline activates transcription of notch and inhibits the proliferation of carcinoid tumor cells. Planta. Med. 78: 1150-1151.

179.Wyche, T. P., A. Dammalapati, H. Cho, A. D. Harrison, G. S. Kwon, H. Chen, T. S. Bugni, and R. Jaskula-Sztul (2014) Thiocoraline activates the Notch pathway in carcinoids and reduces tumor progression in vivo. Cancer Gene Ther. 21: 518-525.

180.Igarashi, Y., H. Ogura, K. Furihata, N. Oku, C. Indananda, and A. Thamchaipenet (2011) Maklamicin, an antibacterial polyketide from an endophytic Micromonospora sp. J. Nat. Prod. 74: 670-674.

181.Tani, K., N. Matsuzawa, S. Yano, and T. Yamaguchi (1982) Studies on a new antibiotic M-92 produced by Micromonospora. I. Taxonomy of M-92 producing Micromonospora and antibiotic production therefrom. J. Antibiot. 35: 1430-1436.

182.Tani, K. and T. Takaishi (1982) Studies on a new antibiotic M-92 produced by Micromonospora. II. Isolation and physicochemical properties of M-92 and its components. J. Antibiot. 35: 1437-1440. 
183.Tani, K., Y. Arai, and T. Yamaguchi (1982) Studies on a new antibiotic M-92 produced by Micromonospora. III. Biological activities. J. Antibiot. 35: 1441-1447.

184.Nelson, R. A., J. A. Pope, Jr., G. M. Luedemann, L. E. McDaniel, and C. P. Schaffner (1986) Crisamicin A, a new antibiotic from Micromonospora. I. Taxonomy of the producing strain, fermentation, isolation, physico-chemical characterization and antimicrobial properties. J. Antibiot. 39: 335-344.

185.Ling, D., L. S. Shield, and K. L. Rinehart, Jr. (1986) Isolation and structure determination of crisamicin A, a new antibiotic from Micromonospora purpureochromogenes subsp. halotolerans. J. Antibiot. 39: 345-353.

186.Yeo, W. H., B. S. Yun, N. I. Back, Y. H. Kim, S. S. Kim, E. K. Park, K. S. Whang, and S. H. Yu (1997) 9-Hydroxycrisamicin A, a new cytotoxic isochromanquinone antibiotic produced by Micromonospora sp. SA246. J. Antibiot. 50: 546-550.

187.Yoon, S. K., I. Y. Park, B. H. Sohn, J. Y. Lee, W. H. Yeo, and Y. I. Lee (2004) A new compound from Micromonospora sp. SA246, 9-hydroxycrisamicin-A, activates hepatitis B virus replication. Biochem. Bioph. Res. Co. 319: 859-865.

188.Matsuda, Y., K. Asano, I. Kawamoto, and H. Kase (1987) K-259-2, a new inhibitor of $\mathrm{Ca}^{2+}$ and calmodulin-dependent cyclic nucleotide phosphodiesterase from Micromonospora olivasterospora. J. Antibiot. 40: 1092-1100.

189.Konishi, M., H. Ohkuma, K. Matsumoto, T. Tsuno, H. Kamei, T. Miyaki, T. Oki, H. Kawaguchi, G. D. VanDuyne, and J. Clardy (1989) Dynemicin A, a novel antibiotic with the anthraquinone and 1,5-diyn-3-ene subunit. J. Antibiot. 42: 1449-1452.

190.Konishi, M., H. Ohkuma, K. Matsumoto, K. Saitoh, T. Miyaki, T. Oki, and H. Kawaguchi (1991) Dynemicins, New antibiotics with the 1, 5-diyn-3-ene and anthraquinone subunit i. Production, isolation and physico-chemical properties. $J$. Antibiot. 44: 6. 
191.Shen, B., Hindra, X. Yan, T. Huang, H. Ge, D. Yang, Q. Teng, J. D. Rudolf, and J. R. Lohman (2015) Enediynes: Exploration of microbial genomics to discover new anticancer drug leads. Bioorg. Med. Chem. Lett. 25: 9-15.

192.Shiomi, K., H. Iinuma, H. Naganawa, M. Hamada, S. Hattori, H. Nakamura, T. Takeuchi, and Y. Iitaka (1990) New antibiotic produced by Micromonospora globosa. J. Antibiot. 43: 1000-1005.

193.Igarashi, Y., M. E. Trujillo, E. Martinez-Molina, S. Yanase, S. Miyanaga, T. Obata, H. Sakurai, I. Salki, F. Tsuyoshi, and T. Furumai (2007) Antitumor anthraquinones from an endophytic actinomycete Micromonospora lupini sp. nov. Bioorg. Med. Chem. Lett. 17: $3702-3705$.

194.Igarashi, Y., S. Yanase, K. Sugimoto, M. Enomoto, S. Miyanaga, M. E. Trujillo, I. Saiki, and S. Kuwahara (2011) Lupinacidin C, an inhibitor of tumor cell invasion from Micromonospora lupini. J. Nat. Prod. 74: 862-865.

195.Wang, H. S., S. L. Yeo, J. Xu, X. L. Xu, H. He, F. Ronca, A. E. Ting, Y. Wang, V. C. Yu, and M. M. Sim (2002) Isolation of streptonigrin and its novel derivative from Micromonospora as inducing agents of p53-dependent cell apoptosis. J. Nat. Prod. 65: $721-724$.

196.Furumai, T., Y. Igarashi, H. Higuchi, N. Saito, and T. Oki (2002) Kosinostatin, a quinocycline antibiotic with antitumor activity from Micromonospora sp. TP-A0468. J. Antibiot. 55: 128-133.

197.Igarashi, Y., H. Higuchi, T. Oki, and T. Furumai (2002) NMR analysis of quinocycline antibiotics: Structure determination of kosinostatin, an antitumor substance from Micromonospora sp. TP-A0468. J. Antibiot. 55: 134-140. 
198.Nair, M. G., S. K. Mishra, A. R. Putnam, and R. C. Pandey (1992) Antifungal Anthracycline antibiotics, Spartanamicin-A and Spartanamicin-B from Micromonospora spp. J. Antibiot. 45: 1738-1745.

199.Ishigami, K., Y. Hayakawa, and H. Seto (1994) Cororubicin, a new anthracycline antibiotic generating active oxygen in tumor-cells. J. Antibiot. 47: 1219-1225.

200.Yang, S. W., T. M. Chan, J. Terracciano, R. Patel, D. Loebenberg, G. D. Chen, M. Patel, V. Gullo, B. Pramanik, and M. Chu (2004) A new anthracycline antibiotic micromonomycin from Micromonospora sp. J. Antibiot. 57: 601-604.

201.Sousa, S., P. C. Jimenez, E. G. Ferreira, E. R. Silveira, R. Braz-Filho, O. D. Pessoa, and L. V. Costa-Lotufo (2012) Anthracyclinones from Micromonospora sp. J. Nat. Prod. 75: 489-493.

202.Marquez, J. A., A. C. Horan, M. Kalyanpur, B. K. Lee, D. Loebenberg, G. H. Miller, M. Patel, and J. A. Waitz (1983) The hazimicins, a new class of antibiotics. Taxonomy, fermentation, isolation, characterization and biological properties. J. Antibiot. 36: 11011108.

203.Shomura, T., N. Nishizawa, M. Iwata, J. Yoshida, M. Ito, S. Amano, M. Koyama, M. Kojima, and S. Inouye (1983) Studies on a new nucleoside antibiotic, dapiramicin. I. Producing organism, assay method and fermentation. J. Antibiot. 36: 1300-1304.

204.Nishizawa, N., Y. Kondo, M. Koyama, S. Omoto, M. Iwata, T. Tsuruoka, and S. Inouye (1984) Studies on a new nucleoside antibiotic, dapiramicin. II. Isolation, physicochemical and biological characterization. J. Antibiot. 37: 1-5.

205.Wu, R. Y., L. M. Yang, T. Yokoi, and K. H. Lee (1988) Neihumicin, a new cytotoxic antibiotic from Micromonospora neihuensis. I. The producing organism, fermentation, isolation and biological properties. J. Antibiot. 41: 481-487. 
206.Yang, L. M., R. Y. Wu, A. T. McPhail, T. Yokoi, and K. H. Lee (1988) Neihumicin, a new cytotoxic antibiotic from Micromonospora neihuensis. II. Structural determination and total synthesis. J. Antibiot. 41: 488-493.

207.Yokoi, T., L. M. Yang, T. Yokoi, R. Y. Wu, and K. H. Lee (1988) Neihumicin, a new cytotoxic antibiotic from Micromonospora neihuensis. III. Structure-activity relationships. J. Antibiot. 41: 494-501.

208.Itoh, J., H. Watabe, S. Ishii, S. Gomi, M. Nagasawa, H. Yamamoto, T. Shomura, M. Sezaki, and S. Kondo (1988) Sibanomicin, a new pyrrolo[1,4]benzodiazepine antitumor antibiotic produced by a Micromonospora sp. J. Antibiot. 41: 1281-1284.

209.Jackson, M., J. P. Karwowski, R. J. Theriault, R. R. Rasmussen, D. M. Hensey, P. E. Humphrey, S. J. Swanson, G. J. Barlow, U. Premachandran, and J. B. Mcalpine (1995) Macquarimicins, microbial metabolites from Micromonospora .1. Discovery, taxonomy, fermentation and biological properties. J. Antibiot. 48: 462-466.

210.Hochlowski, J. E., M. M. Mullally, R. Henry, D. M. Whittern, and J. B. Mcalpine (1995) Macquarimicins, microbial metabolites from Micromonospora. 2. Isolation and structural elucidation. J. Antibiot. 48: 467-470.

211.Ohkuma, H. and S. Kobaru (1996) Compound produced by a strain of Micromonospora. US Patent 5541181.

212.Igarashi, Y., S. Miyanaga, H. Onaka, M. Takeshita, and T. Furumai (2005) Revision of the structure assigned to the antibiotic BU-4664L from Micromonopora. J. Antibiot. 58: $350-352$.

213.Miyanaga, S., H. Sakurai, I. Saiki, H. Onaka, and Y. Igarashi (2010) Anti-invasive and anti-angiogenic activities of naturally occurring dibenzodiazepine BU-4664L and its derivatives. Bioorg. Med. Chem. Lett. 20: 963-965. 
214.Sugawara, T., A. Tanaka, H. Imai, K. Nagai, and K. Suzuki (1997) YM-47515, a novel isonitrile antibiotic from Micromonospora echinospora subsp. echinospora. J. Antibiot. 50: 944-948.

215.Kim, B. S., S. S. Moon, and B. K. Hwang (1999) Isolation, antifungal activity, and structure elucidation of the glutarimide antibiotic, streptimidone, produced by Micromonospora coerulea. J. Agric. Food Chem. 47: 3372-3380.

216.Lam, K. S., J. A. Veitch, D. Brown, Y. Shu, and J. Chen (1999) New antibiotic bravomicins for treating various bacterial diseases, prepared using Micromonospora polytrota. US Patent 5994543.

217.Banskota, A. H., M. Aouidate, D. Sorensen, A. Ibrahim, M. Piraee, E. Zazopoulos, A. M. Alarco, H. Gourdeau, C. Mellon, C. M. Farnet, P. Falardeau, and J. B. McAlpine (2009) TLN-05220, TLN-05223, new Echinosporamicin-type antibiotics, and proposed revision of the structure of bravomicins. J. Antibiot. 62: 565-570.

218.Hernandez, L. M., J. A. Blanco, J. P. Baz, J. L. Puentes, F. R. Millan, F. E. Vazquez, R. I. Fernandez-Chimeno, and D. G. Gravalos (2000) 4'-N-methyl-5'-hydroxystaurosporine and 5'-hydroxystaurosporine, new indolocarbazole alkaloids from a marine Micromonospora sp. strain. J. Antibiot. 53: 895-902.

219.Stefanska, A. L., N. J. Coates, L. M. Mensah, A. J. Pope, S. J. Ready, and S. R. Warr (2000) SB-219383, a novel tyrosyl tRNA synthetase inhibitor from a Micromonospora sp I. Fermentation, isolation and properties. J. Antibiot. 53: 345-350.

220.Houge-Frydrych, C. S. V., S. A. Readshaw, and D. J. Bell (2000) SB-219383, a novel tyrosyl tRNA synthetase inhibitor from a Micromonospora sp. II. Structure determination. J. Antibiot. 53: 351-356. 
221.He, H. Y., W. D. Ding, V. S. Bernan, A. D. Richardson, C. M. Ireland, M. Greenstein, G. A. Ellestad, and G. T. Carter (2001) Lomaiviticins A and B, potent antitumor antibiotics from Micromonospora lomaivitiensis. J. Am. Chem. Soc. 123: 5362-5363.

222.Woo, C. M., N. E. Beizer, J. E. Janso, and S. B. Herzon (2012) Isolation of Lomaiviticins $\mathrm{C}-\mathrm{E}$, transformation of Lomaiviticin $\mathrm{C}$ to Lomaiviticin A, complete structure elucidation of Lomaiviticin A, and structure-activity analyses. J. Am. Chem. Soc. 134: 15285-15288.

223.Colis, L. C., C. M. Woo, D. C. Hegan, Z. W. Li, P. M. Glazer, and S. B. Herzon (2014) The cytotoxicity of (-)-lomaiviticin A arises from induction of double-strand breaks in DNA. Nat Chem. 6: 504-510.

224.Laakso, J. A. and U. M. Mocek (2003) R176502, a new bafilolide metabolite with potent antiproliferative activity from a novel Micromonospora species. J. Antibiot. 56: 909-916.

225.Yang, S. W., T. M. Chan, J. Terracciano, D. Loebenberg, G. D. Chen, M. Patel, V. Gullo, B. Pramanik, and M. Chu (2004) Structure elucidation of a new diketopiperazine Sch 725418 from Micromonospora sp. J. Antibiot. 57: 345-347.

226.He, H. Y., H. Y. Yang, S. W. Luckman, V. S. Bernan, G. Tsai, D. M. Roll, and G. T. Carter (2004) Echinosporamicin, a new antibiotic produced by Micromonospora echinospora ssp. echinospora, LL-P175. Helv. Chim. Acta. 87: 1385-1391.

227.Charan, R. D., G. Schlingmann, J. Janso, V. Bernan, X. D. Feng, and G. T. Carter (2004) Diazepinomicin, a new antimicrobial alkaloid from a marine Micromonospora sp. J. Nat. Prod. 67: 1431-1433.

228.Abdelmohsen, U. R., M. Szesny, E. M. Othman, T. Schirmeister, S. Grond, H. Stopper, and U. Hentschel (2012) Antioxidant and anti-protease activities of diazepinomicin from the sponge-associated Micromonospora strain RV115. Mar. Drugs. 10: 2208-2221.

229.Campas, C. (2009) Diazepinomicin Apoptosis Inducer Oncolytic. Drug Future. 34: 349351. 
230.Abdelmohsen, U. R., K. Bayer, and U. Hentschel (2014) Diversity, abundance and natural products of marine sponge-associated actinomycetes. Nat. Prod. Rep. 31: 381399.

231.Antal, N., H. P. Fiedler, E. Stackebrandt, W. Beil, K. Stroch, and A. Zeeck (2005) Retymicin, galtamycin B, saquayamycin $\mathrm{Z}$ and ribofuranosyllumichrome, novel secondary metabolites from Micromonospora sp. Tu 6368 - I. Taxonomy, fermentation, isolation and biological activities. J. Antibiot. 58: 95-102.

232.Stroch, K., A. Zeeck, N. Antal, and H. P. Fiedler (2005) Retymicin, galtamycin B, saquayamycin $\mathrm{Z}$ and ribofuranosyllumichrome, novel secondary metabolites from Micromonospora sp. Tu 6368 - II. Structure elucidation. J. Antibiot. 58: 103-110.

233. Wagman, G. H., J. A. Marquez, P. D. Watkins, J. V. Bailey, F. Gentile, and M. J. Weinstein (1973) Neomycin production by Micromonospora species 69-683. J. Antibiot. 26: $732-736$.

234.Salauze, D. and J. Davies (1991) Isolation and characterisation of an aminoglycoside phosphotransferase from neomycin-producing Micromonospora chalcea; comparison with that of Streptomyces fradiae and other producers of 4,6-disubstituted 2deoxystreptamine antibiotics. J. Antibiot. 44: 1432-1443.

235.Salauze, D., J. A. Perez-Gonzalez, W. Piepersberg, and J. Davies (1991) Characterisation of aminoglycoside acetyltransferase-encoding genes of neomycin-producing Micromonospora chalcea and Streptomyces fradiae. Gene. 101: 143-148.

236. Valyi-Nagy, T. and G. Kulcsar (1969) Fermentation of primycin. Acta. Biol. Acad. Sci. Hung. 20: 127-140.

237.Weinstein, M. J., G. H. Wagman, M. G. Patel, J. A. Marquez, and S. Corp (1975) Process for producing rifamycin sv. US Patent 3901764. 
238.Huang, H. Q., X. P. Wu, S. Yi, Z. W. Zhou, J. Zhu, Z. Fang, J. M. Yue, and S. X. Bao (2009) Rifamycin S and its geometric isomer produced by a newly found actinomycete, Micromonospora rifamycinica. Anton. Leeuw. Int. J. G. 95: 143-148.

239.Stanzak, R., P. Matsushima, R. H. Baltz, and B. E. Schoner (1990) DNA homology between Saccharopolyspora strains and other erythromycin-producing actinomycetes. $J$. Gen. Microbiol. 136: 1899-1904.

240.Fisher, W. P., J. Charney, and W. A. Bolhofer (1951) An actinomycin from a species of the genus Micromonospora. Antibiot. Chemother. 1: 571-572.

241.Wagman, G. H., J. A. Marquez, P. D. Watkins, F. Gentile, A. Murawski, M. Patel, and M. J. Weinstein (1976) A new actinomycin complex produced by a Micromonospora species: fermentation, isolation, and characterization. Antimicrob. Agents Chemother. 9: $465-469$.

242.Misiek, M., O. B. Fardig, A. Gourevitch, D. L. Johnson, I. R. Hooper, and J. Lein (1957) Telomycin, a new antibiotic. Antibiotics annual. 5: 852-855.

243.Sheehan, J. C., D. Mania, S. Nakamura, J. A. Stock, and K. Maeda (1968) The structure of telomycin. J. Am. Chem. Soc. 90: 462-470.

244.Gurovic, M. S. V., S. Muller, N. Domin, I. Seccareccia, S. Nietzsche, K. Martin, and M. Nett (2013) Micromonospora schwarzwaldensis sp. nov., a producer of telomycin, isolated from soil. Int. J. Syst. Evol. Micr. 63: 3812-3817.

245.Carro, L., P. Pujic, M. E. Trujillo, and P. Normand (2013) Micromonospora is a normal occupant of actinorhizal nodules. J. Biosciences. 38: 685-693.

246.Manivasagan, P., J. Venkatesan, K. Sivakumar, and S.-K. Kim (2014) Pharmaceutically active secondary metabolites of marine actinobacteria. Microbiol. Res. 169: 262-278.

247.Xiang, W. S., C. Yu, C. X. Liu, J. W. Zhao, L. Y. Yang, B. J. Xie, L. Li, K. Hong, and X. J. Wang (2014) Micromonospora polyrhachis sp. nov., an actinomycete isolated from 
edible Chinese black ant (Polyrhachis vicina Roger). Int. J. Syst. Evol. Micr. 64: 495500

248.Zhang, Y. J., H. Liu, X. H. Zhang, S. R. Wang, C. X. Liu, C. Yu, X. J. Wang, and W. S. Xiang (2014) Micromonospora violae sp nov., isolated from a root of Viola philippica Car. Anton. Leeuw. Int. J. G. 106: 219-225.

249.Zhao, J. W., L. F. Guo, H. R. He, C. X. Liu, Y. J. Zhang, C. Li, X. J. Wang, and W. S. Xiang (2014) Micromonospora taraxaci sp. nov., a novel endophytic actinomycete isolated from dandelion root (Taraxacum mongolicum Hand.-Mazz.). Anton. Leeuw. Int. J. G. 106: 667-674.

250.Charlop-Powers, Z., J. G. Owen, B. V. B. Reddy, M. Ternei, D. O. Guimaraes, U. A. de Frias, M. T. Pupo, P. Seepe, Z. Y. Feng, and S. F. Brady (2015) Global Biogeographic Sampling of Bacterial Secondary Metabolism. eLife. 4: e05048.

251.Charlop-Powers, Z., J. G. Owen, B. V. B. Reddy, M. A. Ternei, and S. F. Brady (2014) Chemical-biogeographic survey of secondary metabolism in soil. Proc. Natl. Acad. Sci. U. S. A. 111: 3757-3762.

252.Hayakawa, M., T. Sadakata, T. Kajiura, and H. Nonomura (1991) New methods for the highly selective isolation of Micromonospora and Microbispora from soil. J. Ferment. Bioeng. 72: 320-326.

253.Qiu, D. H., J. S. Ruan, and Y. Huang (2008) Selective isolation and rapid identification of members of the genus Micromonospora. Appl. Environ. Microbiol. 74: 5593-5597.

254.Terahara, T., T. Kobayashi, and C. Imada (2013) An effective method based on wet-heat treatment for the selective isolation of Micromonospora from estuarine sediments. World J. Microb. Biot. 29: 1677-1684.

255.Kurtböke, D. İ. (2010) Exploitation of phage battery in the search for bioactive actinomycetes. Appl. Microbiol. Biotechnol. 89: 931-937. 
256.Prakash, O., Y. Shouche, K. Jangid, and J. E. Kostka (2012) Microbial cultivation and the role of microbial resource centers in the omics era. Appl. Microbiol. Biotechnol. 97: 5162.

257.Li, X. and L. Qin (2005) Metagenomics-based drug discovery and marine microbial diversity. Trends Biotechnol. 23: 539-543.

258.Martinez, J. L. (2008) Antibiotics and antibiotic resistance genes in natural environments. Science. 321: 365-367.

259.Schmieder, R. and R. Edwards (2012) Insights into antibiotic resistance through metagenomic approaches. Future Microbiol. 7: 73-89.

260.Kurtböke, D. İ. (2012) Biodiscovery from rare actinomycetes: an eco-taxonomical perspective. Appl. Microbiol. Biotechnol. 93: 1843-1852.

261.de Castro, A. P., G. D. Fernandes, and O. L. Franco (2014) Insights into novel antimicrobial compounds and antibiotic resistance genes from soil metagenomes. Front. Microbiol. 5: 489.

262.Charlop-Powers, Z., A. Milshteyn, and S. F. Brady (2014) Metagenomic small molecule discovery methods. Curr. Opin. Microbiol. 19: 70-75.

263.Peric-Concha, N., and P. F. Long (2003) Mining the microbial metabolome: a new frontier for natural product lead discovery. Drug Discov. Today. 8: 1078-1084.

264.Wang, Z. W., X. H. Ma, X. Chen, X. M. Zhao, and T. Chen (2010) Current methods and advances in microbial metabolomics. Prog. Chem. 22: 163-172.

265.Aldridge, B. B., and K. Y. Rhee (2014) Microbial metabolomics: innovation, application, insight. Curr. Opin. Microbiol. 19: 90-96.

266.Krug, D. and R. Muller (2014) Secondary metabolomics: the impact of mass spectrometry-based approaches on the discovery and characterization of microbial natural products. Nat. Prod. Rep. 31: 768-783. 
267.Sévin, D. C., A. Kuehne, N. Zamboni, and U. Sauer (2015) Biological insights through nontargeted metabolomics. Curr. Opin. Biotechnol. 34: 1-8.

268.Fang, J. S. and P. C. Dorrestein (2014) Emerging mass spectrometry techniques for the direct analysis of microbial colonies. Curr. Opin. Microbiol. 19: 120-129.

269.Dierig, A., R. Frei, and A. Egli (2015) The fast route to microbe identification matrix assisted laser desorption/ionization-time of flight mass spectrometry (MALDI-TOF MS). Pediatr. Infect. Dis. J. 34: 97-99.

270.Kroppenstedt, R. M., S. Mayilraj, J. M. Wink, W. Kallow, P. Schumann, C. Secondini, and E. Stackebrandt (2005) Eight new species of the genus Micromonospora, Micromonospora citrea sp. nov., Micromonospora echinaurantiaca sp. nov., Micromonospora echinofusca sp. nov., Micromonospora fulviviridis sp. nov., Micromonospora inyonensis sp. nov., Micromonospora peucetia sp. nov., Micromonospora sagamiensis sp. nov., and Micromonospora viridifaciens sp. nov. Syst. Appl. Microbiol. 28: 328-339.

271.Vater, J., I. Crnovcic, S. Semsary, and U. Keller (2014) MALDI- TOF mass spectrometry, an efficient technique for in situ detection and characterization of actinomycins. J. Mass Spectrom. 49: 210-222.

272.Hsu, C. C., M. S. ElNaggar, Y. Peng, J. S. Fang, L. M. Sanchez, S. J. Mascuch, K. A. Moller, E. K. Alazzeh, J. Pikula, R. A. Quinn, Y. Zeng, B. E. Wolfe, R. J. Dutton, L. Gerwick, L. X. Zhang, X. T. Liu, M. Mansson, and P. C. Dorrestein (2013) Real-time metabolomics on living microorganisms using ambient electrospray ionization flowprobe. Anal. Chem. 85: 7014-7018.

273.Kopcakova, A., Z. Stramova, S. Kvasnova, A. Godany, Z. Perhacova, and P. Pristas (2014) Need for database extension for reliable identification of bacteria from extreme environments using MALDI TOF mass spectrometry. Chem. Pap. 68: 1435-1442. 
274.Cox, D. G., J. Oh, A. Keasling, K. L. Colson, and M. T. Hamann (2014) The utility of metabolomics in natural product and biomarker characterization. Biochim. Biophys. Acta. 1840: $3460-3474$.

275.Hou, Y., D. R. Braun, C. R. Michel, J. L. Klassen, N. Adnani, T. P. Wyche, and T. S. Bugni (2012) Microbial strain prioritization using metabolomics tools for the discovery of natural products. Anal. Chem. 84: 4277-4283.

276.Skellam, E. J., A. K. Stewart, W. K. Strangman, and J. L. C. Wright (2013) Identification of micromonolactam, a new polyene macrocyclic lactam from two marine Micromonospora strains using chemical and molecular methods: clarification of the biosynthetic pathway from a glutamate starter unit. J. Antibiot. 66: 431-441.

277.Sato, S., F. Iwata, T. Fukae, and M. Katayama (2014) Neomacquarimicin: a new macquarimicin analog from marine-derived actinomycete. J. Antibiot. 67: 479-482.

278.Fuhrer, T. and N. Zamboni (2015) High-throughput discovery metabolomics. Curr. Opin. Biotechnol. 31: 73-78.

279.de Rond, T., M. Danielewicz, and T. Northen (2015) High throughput screening of enzyme activity with mass spectrometry imaging. Curr. Opin. Biotechnol. 31: 1-9.

280.Beekes, M., P. Lasch, and D. Naumann (2007) Analytical applications of Fourier transform-infrared (FT-IR) spectroscopy in microbiology and prion research. Vet. Microbiol. 123: 305-319.

281.Schultz, E., A. C. Simon, S. A. Strola, R. Perenon, I. Espagnon, C. Allier, P. Claustre, D. Jary, and J. M. Dinten (2014) A novel method for single bacteria identification by Raman spectroscopy. Proc. Spie. 89390D: 1-14.

282.Zhao, H. J., Y. Kassama, M. Young, D. B. Kell, and R. Goodacre (2004) Differentiation of Micromonospora isolates from a coastal sediment in wales on the basis of Fourier 
transform infrared spectroscopy, 16S rRNA sequence analysis, and the amplified fragment length polymorphism technique. Appl. Environ. Microb. 70: 6619-6627.

283.Donadio, S., L. Carrano, L. Brandi, S. Serina, A. Soffientini, E. Raimondi, N. Montanini, M. Sosio, and C. O. Gualerzi (2002) Targets and assays for discovering novel antibacterial agents. J. Biotechnol. 99: 175:186.

284.Nakanishi, S., S. Chiba, H. Yano, I. Kawamoto, and Y. Matsuda (1995) Ms-444, a new inhibitor of myosin light-chain kinase from Micromonospora sp. Ky7123. J. Antibiot. 48: 948-951.

285.Aotani, Y. and Y. Saitoh (1995) Structure determination of Ms-444 - a new myosin lightchain kinase inhibitor. J. Antibiot. 48: 952-953.

286.Meisner, N. C., M. Hintersteiner, K. Mueller, R. Bauer, J. M. Seifert, H. U. Naegeli, J. Ottl, L. Oberer, C. Guenat, S. Moss, N. Harrer, M. Woisetschlaeger, C. Buehler, V. Uhl, and M. Auer (2007) Identification and mechanistic characterization of low-molecularweight inhibitors for HuR. Nat. Chem. Biol. 3: 508-515.

287.Fehr, T., J. J. Sanglier, W. Schuler, L. Gschwind, M. Ponelle, W. Schilling, and C. Wioland (1996) Antascomicins A, B, C, D and E - Novel FKBP12 binding compounds from a Micromonospora strain. J. Antibiot. 49: 230-233.

288.Qin, C., C. Zhang, F. Zhu, F. Xu, S. Y. Chen, P. Zhang, Y. H. Li, S. Y. Yang, Y. Q. Wei, L. Tao, and Y. Z. Chen (2014) Therapeutic target database update 2014: a resource for targeted therapeutics. Nucleic Acids Res. 42: D1118-1123.

289.Donadio, S., P. Monciardini, R. Alduina, P. Mazza, C. Chiocchini, L. Cavaletti, M. Sosio, and A. M. Puglia (2002) Microbial technologies for the discovery of novel bioactive metabolites. J. Biotechnol. 99: 187-198. 
290.Guo, J., F. Huang, C. Huang, X. Duan, X. Jian, F. Leeper, Z. Deng, P. F. Leadlay, and Y. Sun (2014) Specificity and promiscuity at the branch point in gentamicin biosynthesis. Chem. Biol. 21: 608-618.

291.Huang, C., F. Huang, E. Moison, J. Guo, X. Jian, X. Duan, Z. Deng, P. F. Leadlay, and Y. Sun (2015) Delineating the biosynthesis of gentamicin $\mathrm{x} 2$, the common precursor of the gentamicin C antibiotic complex. Chem. Biol. 22: 251-261.

292.Li, D., H. Li, X. Ni, H. Zhang, and H. Xia (2013) Construction of a gentamicin C1aoverproducing strain of Micromonospora purpurea by inactivation of the gacD gene. Microbiol. Res. 168: 263-267.

293.Ni, X., Z. Sun, H. Zhang, H. He, Z. Ji, and H. Xia (2014) Genetic engineering combined with random mutagenesis to enhance G418 production in Micromonospora echinospora. J. Ind. Microbiol. Biotechnol. 41: 1383-1390.

294.Iizaka, Y., N. Higashi, M. Ishida, R. Oiwa, Y. Ichikawa, M. Takeda, Y. Anzai, and F. Kato (2013) Function of cytochrome P450 enzymes RosC and RosD in the biosynthesis of rosamicin macrolide antibiotic produced by Micromonospora rosaria. Antimicrob. Agents Chemother. 57: 1529-1531.

295.Anzai, Y., Y. Iizaka, W. Li, N. Idemoto, S. Tsukada, K. Koike, K. Kinoshita, and F. Kato (2009) Production of rosamicin derivatives in Micromonospora rosaria by introduction of D-mycinose biosynthetic gene with PhiC31-derived integration vector pSET152. J. Ind. Microbiol. Biotechnol. 36: 1013-1021.

296.Iizaka, Y., N. Higashi, W. Li, A. Fukumoto, Y. Anzai, and F. Kato (2014) A new mycinosyl rosamicin derivative produced by an engineered Micromonospora rosaria mutant with a cytochrome P450 gene disruption introducing the D-mycinose biosynthetic gene. J. Ind. Microbiol. Biotechnol. 41: 1451-1456. 
297.Lombo, F., A. Velasco, A. Castro, F. de la Calle, A. F. Brana, J. M. Sanchez-Puelles, C. Mendez, and J. A. Salas (2006) Deciphering the biosynthesis pathway of the antitumor thiocoraline from a marine actinomycete and its expression in two Streptomyces species. Chembiochem. 7: 366-376.

298.Sheoran, A., A. King, A. Velasco, J. M. Pero, and S. Garneau-Tsodikov (2008) Characterization of TioF, a tryptophan 2,3-dioxygenase involved in 3-hydroxyquinaldic acid formation during thiocoraline biosynthesis. Mol. Biosyst. 4: 622-628.

299.Mady, A. S. A., O. E. Zolova, M. San Millan, G. Villamizar, F. de la Calle, F. Lombo, and S. Garneau-Tsodikova (2011) Characterization of TioQ, a type II thioesterase from the thiocoraline biosynthetic cluster. Mol. Biosyst. 7: 1999-2011.

300.Inouye, M., Y. Takada, N. Muto, T. Beppu, and S. Horinouchi (1994) Characterization and expression of a P-450-like mycinamicin biosynthesis gene using a novel Micromonospora Escherichia-coli Shuttle Cosmid Vector. Mol. Gen. Genet. 245: 456464.

301.Anzai, Y., S. Tsukada, A. Sakai, R. Masuda, C. Harada, A. Domeki, S. Y. Li, K. Kinoshita, D. H. Sherman, and F. Kato (2012) Function of cytochrome P450 enzymes MycCI and MycG in Micromonospora griseorubida, a Producer of the macrolide antibiotic mycinamicin. Antimicrob. Agents Chemother. 56: 3648-3656.

302.Li, S. Y., D. R. Tietz, F. U. Rutaganira, P. M. Kells, Y. Anzai, F. Kato, T. C. Pochapsky, D. H. Sherman, and L. M. Podust (2012) Substrate recognition by the multifunctional cytochrome P450 MycG in mycinamicin hydroxylation and epoxidation reactions. $J$. Biol. Chem. 287: 37880-37890.

303.Cochrane, R. V. K., and J. C. Vederas (2014) Highly selective but multifunctional oxygenases in secondary metabolism. Accounts Chem. Res. 47: 3148-3161. 
304.McAlpine, J. B., A. H. Banskota, R. D. Charan, G. Schlingmann, E. Zazopoulos, M. Piraee, J. Janso, V. S. Bernan, M. Aouidate, C. M. Farnet, X. D. Feng, Z. Z. Zhao, and G. T. Carter (2008) Biosynthesis of diazepinomicin/ECO-4601, a Micromonospora secondary metabolite with a novel ring system. J. Nat. Prod. 71: 1585-1590.

305.Ratnayake, A. S., J. E. Janso, X. Feng, G. Schlingmann, I. Goljer, and G. T. Carter (2009) Evaluating indole-related derivatives as precursors in the directed biosynthesis of diazepinomicin analogues. J. Nat. Prod. 72: 496-499.

306.Bonitz, T., F. Zubeil, S. Grond, and L. Heide (2013) Unusual N-prenylation in diazepinomicin biosynthesis: The Farnesylation of a benzodiazepine substrate is catalyzed by a new member of the ABBA prenyltransferase superfamily. PloS one. 8: e85707.

307.Song, H. G., R. Xu, and Z. H. Guo (2015) Identification and characterization of a methionine gamma-Lyase in the calicheamicin biosynthetic cluster of Micromonospora echinospora. Chembiochem. 16: 100-109.

308.Olano, C., F. Lombó, C. Méndez, and J. A. Salas (2008) Improving production of bioactive secondary metabolites in actinomycetes by metabolic engineering. Metab. Eng. 10: $281-292$.

309.Lee, S. Y., H. U. Kim, J. H. Park, J. M. Park, and T. Y. Kim (2009) Metabolic engineering of microorganisms : General strategies and drug production. Drug Discov. Today. 14: 78-88.

310.Wang, Y., J. Chu, Y. Zhuang, Y. Wang, J. Xia, and S. Zhang (2009) Industrial bioprocess control and optimization in the context of systems biotechnology. Biotech. Adv. 27: 989995.

311.Kumar, C. G., M. Himabindu, and A. Jetty (2008) Microbial biosynthesis and applications of gentamicin: a critical appraisal. Crit. Rev. Biotechnol. 28: 173-212. 
312.Charney, W. and S. Corp (1964) Manufacture of gentamycin. US Patent 3136704.

313.Abou-Zeid, A. A., and A. I. Eissa (1974) The Fermentative Production of Gentamicins by Micromonospora purpurea. J. appl. Chem. Biotechnol. 24: 655-662.

314.Gonzalez, R., L. Islas, A.-M. Obregon, L. Escalante, and S. Sanchez (1994) Gentamicin in Micromonospora purpurea: Stimilatory effect of ammonium. J. Antibiot. 48: 479-484.

315.Himabindu, M., P. Ravichandra, K. Vishalakshi, and A. Jetty (2006) Optimization of critical medium components for the maximal production of gentamicin by Micromonospora echinospora ATCC 15838 using response surface methodology. Appl. Biochem. Biotechnol. 134: 143-154.

316.Choi, D., S. S. Park, B. K. Ahn, D. H. Lim, Y. W. Lee, J. H. Moon, and D. Y. Shin (2008) Studies on production of gentamicin from Micromonosporas purpurea using crude vegetable oils. Process. Biochem. 43: 835-841.

317.Chu, J., S. L. Zhang, Y. P. Zhuang, J. Chen, and Y. R. Li (2002) Factors affecting the biosynthesis and secretion of gentamicin. Process. Biochem. 38: 815-820.

318.Raju, C. A. I., C. V. Satya, C. C. Mehta, N. M. Yugandhar, and S. Subba Rao ( 2012) Optimization of media composition for the production of gentamycin by Micromonospora echinospora MTCC 708 using response surface methodology. IJMER. 2: $1267-1273$.

319.Mousdale, D., B. Mcneil, E. M. T. El-Mansi, C. F. A. Bryce, and A. L. Demain (2011) Applications of metabolomics to microbial "Cell Factories" for biomanufacturing: current trends and future prospects. pp. 138-160. In: E. M. T. El-Mansi, C. F. A. Bryce, Arnold L. Demain, and A.R. Allman (eds.). Fermentation microbiology and biotechnology. CRC Press, Boca Raton, USA. 
320.Zhang, D.-L., J. Chu, and Y.-R. Li (2002) Influence of dissolved oxygen and phosphate on the synthesis and secretion of gentamicin. Zhongguo Kangshengsu Zazhi. 28: 145147.

321.Reisman, H. B. (1993) Problems in scale-up of biotechnology production processes. Crit. Rev. Biotechnol. 13: 195-253.

322.Chu, J., B. L. Li, S. L. Zhang, and Y. R. Li (2000) On-line ultrasound stimulates the secretion and production of gentamicin by Micromonospora echinospora. Process Biochem. 35: 569-572.

323.Luedemann, G. M. and M. J. Weinstein (1963) Gentamycin and method of production. US Patent 3091572.

324.Grote, J., R. Himmelsbach, and D. Johnson (2012) Methodology for the rapid separation of gentamicin components and regiospecific synthesis of gentamicin conjugates. Tetrahedron Lett. 53: 6751-6754.

325.AFSSA - Agence française de sécurité sanitaire des produits de sante (2012) Update on good use of injectable aminoglycosides, gentamycin, tobramycin, netilmycin, amikacin. Pharmacological properties, indications, dosage, and mode of administration, treatment monitoring. Med Mal Infect. 42: 301-308.

326.Venisse, N., A. Dupuis, J. Badin, R. Robert, M. Pinsard, and A. Veinstein (2015) Efficacy and safety of high-dose gentamicin re-dosing in ICU patients receiving haemodialysis. $J$. Antimicrob. Chemoth. 70: 308-310.

327.Vucicevic-Prcetic, K., R. Cservenak, and N. Radulovic (2011) Development and validation of liquid chromatography tandem mass spectrometry methods for the determination of gentamicin, lincomycin, and spectinomycin in the presence of their impurities in pharmaceutical formulations. J. Pharm. Biomed. Anal. 56: 736-742. 
328.Li, B., A. Van Schepdael, J. Hoogmartens, and E. Adams (2011) Mass spectrometric characterization of gentamicin components separated by the new European Pharmacopoeia method. J. Pharm. Biomed. Anal. 55: 78-84.

329.Testa, R. T., G. H. Wagman, P. J. Daniels, and M. J. Weinstein (1974) Mutamicins; biosynthetically created new sisomicin analogues. J. Antibiot. 27: 917-921.

330.Huong, N. L., N. H. Hoang, A. Shrestha, J. K. Sohng, Y. J. Yoon, and J. W. Park (2014) Biotransformation of rosamicin antibiotic into 10,11-dihydrorosamicin with enhanced in vitro antibacterial activity against MRSA. J. Microbiol. Biotechnol. 24: 44-47.

331.Mandala, S. M., R. A. Thornton, J. Milligan, M. Rosenbach, M. Garcia-Calvo, H. G. Bull, G. Harris, G. K. Abruzzo, A. M. Flattery, C. J. Gill, K. Bartizal, S. Dreikorn, and M. B. Kurtz (1998) Rustmicin, a potent antifungal agent, inhibits sphingolipid synthesis at inositol phosphoceramide synthase. J Biol Chem. 273: 14942-14949.

332.Shafiee, A., G. Harris, H. Motamedi, M. Rosenbach, T. Chen, D. Zink, and B. Heimbuch (2001) Microbial hydroxylation of rustmicin (galbonolide A) and galbonolide B, two antifungal products produced by Micromonospora sp. J. Mol. Catal. B-Enzym. 11: 237242.

333.Chaudhary, M., G. K. Naidu, S. Kumar, and A. Payasi (2012) Comparative antibacterial activity of a novel semisynthetic antibiotic: etimicin sulphate and other aminoglycosides. World J. Microb. Biot. 28: 3365-3371.

334.Wu, K., X. Zhao, Z. Zhang, X. Zhou, T. Dong, B. Li, X. Sun, Q. Yang, and L. Zhang (2014) Etimicin sulfate preparation by reacting gentamicin $\mathrm{C} 1 \mathrm{a}$ and fluorene methoxycarbonyl chloride, reacting with acetaldehyde, triacetoxy sodium borohydride and piperidine, purifying twice, and reacting with concentrated sulfuric acid. CN Patent 104231016. 
335.Jones, R. N. (1995) Isepamicin (SCH 21420, 1-N-HAPA gentamicin B): microbiological characteristics including antimicrobial potency of spectrum of activity. J. Chemother. 7 Suppl. 2: 7-16.

336.Tann, C. H., T. K. Thiruvengadam, J. S. Chiu, C. Colon, and M. D. Green (1995) Process for preparing isepamicin. US Patent 5442047.

337.Falagas, M. E., D. E. Karageorgopoulos, G. G. Georgantzi, C. Sun, R. Wang, and P. I. Rafailidis (2012) Susceptibility of Gram-negative bacteria to isepamicin: a systematic review. Expert. Rev. Anti. Infect. Ther. 10: 207-218.

338.Phillips, I., A. Smith, and K. Shannon (1977) Antibacterial activity of netilmicin, a new aminoglycoside antibiotic, compared with that of gentamicin. Antimicrob. Agents Chemother. 11: 402-406.

339.Zhanel, G. G., C. D. Lawson, S. Zelenitsky, B. Findlay, F. Schweizer, H. Adam, A. Walkty, E. Rubinstein, A. S. Gin, D. J. Hoban, J. P. Lynch, and J. A. Karlowsky (2012) Comparison of the next-generation aminoglycoside plazomicin to gentamicin, tobramycin and amikacin. Expert. Rev. Anti-Infe. 10: 459-473.

340.Bassetti, M. and E. Righi (2015) Development of novel antibacterial drugs to combat multiple resistant organisms. Langenbecks Arch. Surg. 400: 153-165.

341.Olsen, S. C. and S. A. Carlson (2015) In vitro bactericidal activity of aminoglycosides, including the next-generation drug plazomicin, against Brucella spp. Int. J. Antimicrob. Ag. 45: 76-78.

342.Kondo, J., M. Koganei, J. P. Maianti, V. L. Ly, and S. Hanessian (2013) Crystal structures of a bioactive 6 '-hydroxy variant of sisomicin bound to the bacterial and protozoal ribosomal decoding sites. Chem. Med. Chem. 8: 733-739. 
343.Boger, D. L. and S. Ichikawa (2000) Total syntheses of thiocoraline and BE-22179 : Establishment of relative and absolute stereochemistry. J. Am. Chem. Soc. 122: 29562957.

344.Boger, D. L., S. Ichikawa, W. C. Tse, M. P. Hedrick, and Q. Jin (2001) Total syntheses of thiocoraline and BE-22179 and assessment of their DNA binding and biological properties. J. Am. Chem. Soc. 123: 561-568.

345.Zamudio-Vaazquez, R., F. Albericio, J. Tulla-Puche, and K. R. Fox (2014) Thioester bonds of thiocoraline can be replaced with nme-amide bridges without affecting its dnabinding properties. Acs. Med. Chem. Lett. 5: 45-50.

346.Tulla-Puche, J., N. Bayo-Puxan, J. A. Moreno, A. M. Francesch, C. Cuevas, M. Alvarez, and F. Albericio (2007) Solid-phase synthesis of oxathiocoraline by a key intermolecular disulfide dimer. J. Am. Chem. Soc. 129: 5322-5323

347.Bayo-Puxan, N., J. Tulla-Puche, and F. Albericio (2009) Oxathiocoraline: Lessons to be learned from the synthesis of complex N-methylated depsipeptides. Eur. J. Org. Chem. $2957-2974$.

348. Tatsuta, K., T. Yoshimoto, and H. Gunji (1997) Total synthesis of MS-444, a myosin light chain kinase inhibitor. J. Antibiot. 50: 289-290.

349.Wieczner, J. (2015) Biotech pros' top 8 stock picks. Fortune magazine. http://fortune.com/2015/03/09/biotech-pros-top-8-stock-picks/

350.Transparency Market Research - TMR (2014) Antibacterial drugs market (by class and pipeline analysis) - global industry analysis, size, share, growth, trends and forecast, 2013-2019 - market research report. http://www.reportlinker.com/p02063560summary/Antibacterial-Drugs-Market-By-Class-and-Pipeline-Analysis-Global-IndustryAnalysis-Size-Share-Growth-Trends-and-Forecast.html 
351.Tidmarsh, G. F. (2015) La Jolla pharmaceutical company acquires rights to nextgeneration gentamicin derivatives. http://www.businesswire.com/news/home/20150507006697/en/La-Jolla-PharmaceuticalCompany-Acquires-Rights-Next-Generation

352.Theuretzbacher, U., F. Van Bambeke, R. Canton, C. G. Giske, J. W. Mouton, R. L. Nation, M. Paul, J. D. Turnidge, and G. Kahlmeter (2015) Reviving old antibiotics. J. Antimicrob. Chemother. 70: 2177-2181. 


\section{Table 1.}

Antibiotics molecules produced by the genus Micromonospora

\section{Legend for Figures}

Fig. 1. Chemical structure of some antibiotics produced by different Micromonospora strains. The molecular structures were downloaded from ChemSpider [356].

Fig. 2. Different approaches used in the development of new antibiotics from the genus Micromonospora. 
Table 1. Antibiotics molecules produced by the genus Micromonospora 


\begin{tabular}{|c|c|c|c|c|c|c|}
\hline Antibiotic & Class & Strain & Source & Year & Biological Activity & Ref. \\
\hline Micromonosporin & Chromoprotein & Micromonospora sp. & Soil & 1947 & Antibacterial activity & [29] \\
\hline Actinomycins & Polypeptide & Micromonospora sp. 608 & - & 1951 & Anticancer activity & [236] \\
\hline Gentamicins & Aminoglycosides & $\begin{array}{l}\text { M. echinospora NRRL } 2953 \\
\text { M. echinospora NRRL } 2985\end{array}$ & $\begin{array}{l}\text { Soil, New York, USA } \\
\text { Soil, New York, USA }\end{array}$ & 1963 & Antibacterial activity & [37] \\
\hline Everninomicins & Oligosaccharides & $\begin{array}{l}\text { M. carbonacea NRRL } 2972 \\
\text { M. carbonacea subsp. aurantiaca NRRL } \\
2997 \\
\text { M. carbonacea var. africana ATCC } 39149\end{array}$ & $\begin{array}{l}\text { Soil, New York, USA } \\
\text { Soil, New York, USA } \\
\text { Soil, Kenya }\end{array}$ & 1964 & Antibacterial activity & $\begin{array}{l}{[38,} \\
137]\end{array}$ \\
\hline Halomicins & Ansamysins & $\begin{array}{l}\text { M. halophytica subsp. halophytica NRRL } \\
2998 \\
\text { M. halophytica subsp. nigra NRRL } 3097\end{array}$ & $\begin{array}{l}\text { Salt pool, Syracuse, } \\
\text { New York, USA }\end{array}$ & 1967 & Antibacterial activity & [146] \\
\hline Antibiotic 460 & Aminoglycosides & M. chalcea subsp. flavida NRRL 3222 & Soil, New York, USA & 1969 & Antibacterial activity & {$[50]$} \\
\hline Megalomicins & Macrolides & $\begin{array}{l}\text { M. megalomicea subsp. megalomicea NRRL } \\
3274 \\
\text { M. megalomicea subsp. nigra NRRL } 3275\end{array}$ & Soil & 1969 & $\begin{array}{l}\text { Antibacterial activity } \\
\text { Antiparasitic activity } \\
\text { Antiviral activity }\end{array}$ & [79, \\
\hline Primycin & Macrolides & M. galeriensis & - & 1969 & $\begin{array}{l}\text { Antibacterial activity } \\
\text { Antifungal activity }\end{array}$ & $\begin{array}{l}{[38,} \\
232]\end{array}$ \\
\hline Sisomicin & Aminoglycosides & M. inyoensis NRRL 3292 & Soil, California, USA & 1970 & Antibacterial activity & [51] \\
\hline Rosamicin & Macrolides & M. rosaria NRRL 3718 & Soil, Texas, USA & 1972 & Antibacterial activity & [84] \\
\hline Neomycin B & Aminoglycosides & M. chalcea $69-683$ & - & 1973 & Antibacterial activity & [229] \\
\hline Verdamicin & Aminoglycosides & M. grisea NRRL 3800 & Soil, Kansas, USA. & 1974 & Antibacterial activity & [59] \\
\hline Mutamicins & Aminoglycosides & M. inyoensis NRRL 3292 & Soil, California, USA & 1974 & Antibacterial activity & [325] \\
\hline Sagamicin & Aminoglycosides & $\begin{array}{l}\text { M. sagamiensis subsp. nonreducans ATCC } \\
21803 \\
\text { M. sagamiensis ATCC } 21826\end{array}$ & $\begin{array}{l}\text { Soil, Illinois, USA } \\
\text { Soil, Kanagawa, Japan }\end{array}$ & 1974 & Antibacterial activity & $\begin{array}{l}{[60,} \\
61]\end{array}$ \\
\hline Antibiotic G-418 & Aminoglycosides & M. echinospora NRRL 5326 & Soil & 1974 & $\begin{array}{l}\text { Antibacterial activity } \\
\text { Antiparasitic activity } \\
\text { Selective agent for } \\
\text { mammalian cell } \\
\text { studies }\end{array}$ & $\begin{array}{l}{[46,} \\
47]\end{array}$ \\
\hline Bottromycin & $\begin{array}{l}\text { Macrocyclic } \\
\text { peptide }\end{array}$ & M. chalcea FERM-P 1823 & - & 1974 & Antibacterial activity & [38] \\
\hline Antibiotics JI-20 & Aminoglycosides & M. echinospora NRRL 5467 & Soil, New York, USA & 1975 & Antibacterial activity & $\begin{array}{l}{[38,} \\
49]\end{array}$ \\
\hline
\end{tabular}




\begin{tabular}{|c|c|c|c|c|c|c|}
\hline Rifamycins & Ansamysins & M. lacustris ATCC 21975 & Mud, Connecticut, USA & 1975 & Antibacterial activity & [233] \\
\hline Antibiotic G-52 & Aminoglycosides & M. zionensis NRRL 5466 & Soil, Utah, USA & 1975 & Antibacterial activity & [56] \\
\hline Fortimicins & Aminoglycosides & M. olivasterospora ATCC 21819 & Soil. Hiroshima, Japan & 1976 & Antibacterial activity & [63] \\
\hline Juvenimicins & Macrolides & M. chalcea subsp. izumensis ATCC 21561 & Soil, Osaka, Japan & 1976 & Antibacterial activity & [90] \\
\hline Erythromycin B & Macrolides & Micromonospora sp. 1225 & - & 1976 & Antibacterial activity & {$[38]$} \\
\hline Mycinamicins & Macrolides & M. grisseorubida A11725 & Soil, Toyama, Japan & 1980 & Antibacterial activity & [93] \\
\hline Antlermicins & Aminoglycosides & M. chalcea subsp. kazitnoensis T-90 & Soil, Akita, Japan & 1980 & $\begin{array}{l}\text { Antibacterial activity } \\
\text { Anticancer activity }\end{array}$ & $\begin{array}{l}{[70,} \\
71]\end{array}$ \\
\hline Tetrocarcins & Aminoglycosides & M. chalcea KY11091 & Soil, Miyagi, Japan & 1980 & $\begin{array}{l}\text { Antibacterial activity } \\
\text { Anticancer activity }\end{array}$ & [349] \\
\hline Izumenolide & Lactones & M. chalcea subsp. izumensis SC 11133 & Soil, South Africa & 1980 & Antibacterial activity & [114] \\
\hline $\begin{array}{l}\text { N-(2,6-Diamino-6- } \\
\text { hydroxymethylpimel } \\
\text { yl)-L-alanine }\end{array}$ & Dipeptide & M. chalcea $\mathrm{PA}-3534$ & $\begin{array}{l}\text { Soil, Ariake } \\
\text { Bay, Fukuoka. Japan }\end{array}$ & 1981 & Antibacterial activity & [153] \\
\hline $\begin{array}{l}\text { L-2-(1- } \\
\text { Methylcyclopropyl) } \\
\text { glycine }\end{array}$ & Amino acid & M. miyakonensis PA-4046 & Soil, Okinawa, Japan & 1981 & Antibacterial activity & $\begin{array}{l}{[154,} \\
155]\end{array}$ \\
\hline Combimicins & Aminoglycoside & $\begin{array}{l}\text { Micromonospora sp. ATCC } 31348 \\
\text { Micromonospora sp. ATCC } 31349\end{array}$ & Soil, Japan & 1981 & Antibacterial activity & {$[76]$} \\
\hline M-92 & Naphthoquinones & M. verruculosa M-92 & $\begin{array}{l}\text { Soil, Nago City, } \\
\text { Okinawa, Japan }\end{array}$ & 1982 & $\begin{array}{l}\text { Antibacterial activity } \\
\text { Anticancer activity }\end{array}$ & [177] \\
\hline Hazimicins & Nitriles & $\begin{array}{l}\text { M. echinospora var. challisensis SCC } \\
1411\end{array}$ & Soil, Challis, Idaho. USA & 1983 & $\begin{array}{l}\text { Antibacterial activity } \\
\text { Anti- yeast avtivity }\end{array}$ & [198] \\
\hline Dapiramicin & Ribonucleosides & Micromonospora sp. SF-1917 & Soil, Japan & 1983 & Antifungal activity & [199] \\
\hline Rustmicin & Macrolides & M. chalcea $980-\mathrm{MC} 1$ & Soil, Japan & 1985 & Antifungal activity & [120] \\
\hline Clostomicins & Macrolide & $\begin{array}{l}\text { M. echinospora subsp. armeniaca KMR- } \\
593\end{array}$ & Soil, Niigata, Japan & 1986 & Antibacterial activity & [122] \\
\hline Crisamicin A & Naphthoquinones & $\begin{array}{l}\text { M. purpureochromogenes subsp. } \\
\text { halotolerans RV-79-9-101 }\end{array}$ & Mud sample, Philippines & 1986 & $\begin{array}{l}\text { Antibacterial activity } \\
\text { Anticancer activity }\end{array}$ & [180] \\
\hline $\mathrm{K}-13$ & Cyclic Peptides & M. halophytica subsp. exilisia K-13 & Soil & 1987 & $\begin{array}{l}\text { Inhibitor of angiotensin } \\
\text { I converting enzyme } \\
\text { (ACE) }\end{array}$ & [156] \\
\hline K-259-2 & Anthraquinone & M. olivasterospora K-259 & $\begin{array}{l}\text { Soil, Nagaizumi-cho, } \\
\text { Sunto-gun, Shizuoka, } \\
\text { Japan }\end{array}$ & 1987 & $\begin{array}{l}\text { Inhibitor of Ca2+ and } \\
\text { calmodulin-dependent }\end{array}$ & 184] \\
\hline
\end{tabular}




$\begin{array}{ll}\begin{array}{l}\text { Sch } 37137 \\ \text { Neihumicin }\end{array} & \begin{array}{l}\text { Dipeptides } \\ \text { Pyrazines }\end{array} \\ \text { Sibanomicin } & \begin{array}{l}\text { Pyrrole- } \\ \text { Benzodiazepines }\end{array} \\ \text { LL-E19085 alpha } & \begin{array}{l}\text { Oxazoles } \\ \text { Calicheamicins }\end{array} \\ \text { Enediynes }\end{array}$

Citreamicins
Dynemicin A

Deoxydynemicin A

Trehazolin

Spartanamicins

Trehalamine

Quinolidomicins

$\mathrm{AC} 6 \mathrm{H}$

MS-444

Cororubicin

Macquarimicins

Oxazoles

Anthraquinone

Anthraquinone

Pseudodisaccharide

Anthracycline

Oxazoles

Macrolides

Aminoglycoside

Naphthols

Anthracycline

Oxabicyclo[6.2.2]
Micromonospora sp. SCC 1792

M. neihuenis NH3-1 Wu

\section{Micromonospora sp. SF2364}

M. citrea NRRL 18351

M. echinospora sp. calichensis. NRRL 15839

M. echinospora sp. calichensis NRRL

15975

M. echinospora sp. calichensis NRRL

18149

M. citrea NRRL 18351

M. chersina ATCC 53710

M. globosa FERM P-10651

Micromonospora sp. SANK 62390

Micromonospora sp. ATCC 53803

Micromonospora sp. SANK 62390

Micromonospora sp. JY16 - FERM BP-

3940

M. carbonaceae subsp. carbonaceae K55AC6

Micromonospora sp. KY7123

Micromonospora sp. JY16

M. chalcea AB 965S-73

Systems
Soil, South Africa

Soil, Nei-Hu, near

Taipei, Taiwan

Soil, Tanzania

Soil, Texas, USA

Soil, Tanzania

Soil, India

Soil, Japan

Soil, Tochigi, Japan

Soil

Soil, Nikko, Tochigi,

Japan

Soil, Gunma, Japan

Soil, Hyogo, Japan

Soil, Okinawa,

Japan

Soil, Gunma, Japan

Soil, Sydney, Australia

Soil, Virginia, USA cyclic nucleotide

phosphodiesterase

1988 Antifungal activity

Cytotoxic activity

Antifungal activity

1988

Anticancer activity

158

[201]

1989

Antibacterial activity

[204]

1989

Antibacterial activity

[148]

Anticancer activity

106 ,

107]

1990 Antibacterial activity

1989 Antibacterial activity

1990 Antibacterial activity

1991 Trehalase glycosidase

1992 Antifungal activity

1993 Antitumoral activity

1993 Antitumor activity

1993

1994

1995
Anticancer activity

inhibitor

Inhibit rat intestinal

sucrase

[124]

[77]

Vasodilator/

[280

Bronchodilator

Antitumoral activity

351]

Cytotoxic activity

[195]

149]

[188]

144]

94]

$24]$

Antitumoral activity 


\begin{tabular}{|c|c|c|c|c|c|c|}
\hline Korkormicins & $\begin{array}{l}\text { Peptidic } \\
\text { compounds }\end{array}$ & Micromonospora sp. C39500 & Soil & 1995 & Antitumoral activity & [159] \\
\hline Rakicidin A & Cyclic depsipeptide & Micromonospora sp. R385-2 & $\begin{array}{l}\text { Soil, Andhra Pradesh, } \\
\text { India }\end{array}$ & 1995 & $\begin{array}{l}\text { Cytotoxic : Hypoxia- } \\
\text { Selective Cytotoxin }\end{array}$ & [163] \\
\hline Antascomicins & $\begin{array}{l}\text { Macrocyclic } \\
\text { lactones }\end{array}$ & Micromonospora sp. DSM 8429 & Soil, China & 1996 & $\begin{array}{l}\text { Antagonize the } \\
\text { immunosuppressive } \\
\text { activity of FK506 and } \\
\text { rapamycin (FKBP12 } \\
\text { binding molecules) }\end{array}$ & [283] \\
\hline BU-4664L & Dibenzazepines & Micromonospora sp. ATCC 55378 & Soil, Colombo, Sri Lanka & 1996 & $\begin{array}{l}\text { Anti-inflammatory } \\
\text { anti-tumor cell } \\
\text { activities }\end{array}$ & [207] \\
\hline Pyrrolosporin A & Macrolides & Micromonospora sp. ATCC 53791 & Soil, Puerto Viejo, Peru & 1996 & $\begin{array}{l}\text { Antibacterial activity } \\
\text { Antitumor antibiotic }\end{array}$ & [126] \\
\hline 9-Hydroxycrisamicin-A & Naphthoquinone & Micromonospora sp. SA246 & Soil, Taejon, Korea & 1997 & $\begin{array}{l}\text { Cytotoxic antibiotic, } \\
\text { Activate hepatitis B } \\
\text { virus (HBV) replication }\end{array}$ & $\begin{array}{l}{[182,} \\
183]\end{array}$ \\
\hline Thiocoraline & Thiodepsipeptide & $\begin{array}{l}\text { Micromonospora sp. ACM2-092 } \\
\text { Micromonospora sp. ML1 }\end{array}$ & $\begin{array}{l}\text { Soft coral and mollusc, } \\
\text { Mozambique }\end{array}$ & 1997 & $\begin{array}{l}\text { Antibacterial activity } \\
\text { Anticancer activity }\end{array}$ & [169] \\
\hline YM-47515 & Isonitrile compound & $\begin{array}{l}\text { M. echinospora subsp. echinospora Y- } \\
\text { 03559J }\end{array}$ & Soil, Saitama, Japan & 1997 & Antibacterial activity & [210] \\
\hline Cymbimicin A and B & Lactone & Micromonospora sp. DSM 8594 & Soil, Bromo, Indonesia & 1997 & $\begin{array}{l}\text { Cyclophilin-binding } \\
\text { structures } \\
\text { immuno-suppressive }\end{array}$ & [129] \\
\hline Sch 40832 & Thiostrepton & M. carbonacea var. africana ATCC 39149 & Soil, Kenya & 1998 & Antibacterial activity & [150] \\
\hline $\begin{array}{l}\text { Streptimidone } \\
\text { Ao58A }\end{array}$ & Glutarimide & M. coerulea Ao58 & $\begin{array}{l}\text { Sea-mud soil, Young- } \\
\text { Jong island, Korea }\end{array}$ & 1999 & Antifungal activity & [211] \\
\hline Bravomicins & Bravomicins & M. $p o$ & Soil & 1999 & Antibacte & [212] \\
\hline IB-96212 & Macrolide & Micromonospora sp. CECT 3333 & $\begin{array}{l}\text { Homogenates of a } \\
\text { sponge, Indian Ocean. } \\
\text { Coast of Mozambique }\end{array}$ & 2000 & Cytotoxic activity & [130] \\
\hline Arisostatins & Tetrocarcin & Micromonospora sp. TP-A0316 & $\begin{array}{l}\text { Seawater sample, } \\
\text { Toyama Bay, Japan }\end{array}$ & 2000 & $\begin{array}{l}\text { Antibacterial activity } \\
\text { Antitumor activity }\end{array}$ & [133] \\
\hline $\begin{array}{l}\text { 4'-N-Methyl- } \\
\text { 5'hydroxystaurosporine } \\
\text { 5'-hydroxystaurosporine }\end{array}$ & $\begin{array}{l}\text { Indolocarbazole } \\
\text { alkaloids }\end{array}$ & Micromonospora sp.L-31-CLCO-002 & $\begin{array}{l}\text { Sponge Clathrina } \\
\text { Coriacea, Canary Islands } \\
\text { archipielago }\end{array}$ & 2000 & Cytotoxic activity & [214] \\
\hline
\end{tabular}




\begin{tabular}{|c|c|c|c|c|c|c|}
\hline SB-219383 & Furan & Micromonospora sp. NCIMB 40684 & Soil, South Africa & 2000 & Antibacterial activity & {$[215]$} \\
\hline Lomaiviticins & $\begin{array}{l}\text { Dimeric } \\
\text { diazobenzofluorene } \\
\text { glycosides }\end{array}$ & M. lomaivitiensis LL-37I366 & $\begin{array}{l}\text { Ascidian } \\
\text { Polysyncratonlithostrotu } \\
m\end{array}$ & 2001 & Antitumor antibiotics & [217] \\
\hline $\begin{array}{l}\text { Streptonigrin } \\
\text { 7-(1-methyl-2 } \\
\text { oxopropyl)streptonigrin }\end{array}$ & Quinone & Micromonospora sp. IM 2670 & $\begin{array}{l}\text { Soil, Botanic Garden, } \\
\text { Singapore }\end{array}$ & 2002 & Cytotoxic activity & {$[191]$} \\
\hline Kosinostatin & Quinocycline & Micromonospora sp. TP-A0468 & $\begin{array}{l}\text { Seawater sample, } \\
\text { Toyama. Japan. }\end{array}$ & 2002 & $\begin{array}{l}\text { Antibacterial activity } \\
\text { Cytotoxic }\end{array}$ & [192] \\
\hline R176502 & $\begin{array}{l}\text { Bafilolide } \\
\text { metabolite }\end{array}$ & Micromonospora sp. JS1035 & $\begin{array}{l}\text { River bottom sediment, } \\
\text { Cameroon }\end{array}$ & 2003 & Antiproliferative & {$[220]$} \\
\hline Micromonomycin & Anthracycline & Micromonospora sp. & - & 2004 & $\begin{array}{l}\text { Antibacterial activity } \\
\text { Antifungal activity }\end{array}$ & [196] \\
\hline Micromonosporin A & Macrolide & Micromonospora sp. & $\begin{array}{l}\text { Acidic peat swamp } \\
\text { forest, Thailand }\end{array}$ & 2004 & & [135] \\
\hline Sch 725418 & Diketopiperazine & Micromonospora sp. & - & 2004 & Antifungal activity & {$[221]$} \\
\hline Echinosporamicin & $\begin{array}{l}\text { Aromatic } \\
\text { polycyclic system } \\
\text { and a piperazinone } \\
\text { moiety }\end{array}$ & $\begin{array}{l}\text { M. echinospora subsp. echinospora LL- } \\
\text { P175 }\end{array}$ & $\begin{array}{l}\text { Soil, tidepool near } \\
\text { Ventura, California, } \\
\text { USA }\end{array}$ & 2004 & Antibacterial activity & {$[222]$} \\
\hline Diazepinomicin & $\begin{array}{l}\text { Natural } \\
\text { dibenzodiazepine }\end{array}$ & $\begin{array}{l}\text { Micromonospora sp. DPJ12 } \\
\text { Micromonospora sp. RV115 }\end{array}$ & $\begin{array}{l}\text { Ascidian Didemnum } \\
\text { proliferum, Japan } \\
\text { Sponge Aplysina } \\
\text { aerophoba, Croatia }\end{array}$ & 2004 & $\begin{array}{l}\text { Anticancer activity } \\
\text { Anti-inflammatory } \\
\text { Antiparasitic activity }\end{array}$ & $\begin{array}{l}{[223,} \\
224]\end{array}$ \\
\hline Retymicin & Xanthone & Micromonospora sp. Tü 6368 & Soil, Romania & 2005 & Cytostatic effects & {$[227]$} \\
\hline Galtamycin B & Galtamycin & Micromonospora sp. Tü 6368 & Soil, Romania & 2005 & Cytostatic effects & {$[227]$} \\
\hline Saquayamycin $\mathrm{Z}$ & Saquayamycin & Micromonospora sp. Tü 6368 & Soil, Romania & 2005 & Cytostatic effects & {$[227]$} \\
\hline Lupinacidins & Anthraquinones & M. lupine Lupac 08 & $\begin{array}{l}\text { Root nodules of Lupinus } \\
\text { angustifolius, Spain }\end{array}$ & 2007 & $\begin{array}{l}\text { anti-invasive activity } \\
\text { against murine colon } \\
\text { 26-L5 carcinoma } \\
\text { cells }\end{array}$ & [189] \\
\hline $\begin{array}{l}\text { TLN-05220, } \\
\text { TLN-05223 }\end{array}$ & $\begin{array}{l}\text { Echinosporamicin- } \\
\text { type antibiotics }\end{array}$ & $\begin{array}{l}\text { M. echinospora subsp. challisensis NRRL } \\
12255\end{array}$ & USA & 2009 & $\begin{array}{l}\text { Antibacterial activity } \\
\text { Anticancer activity }\end{array}$ & {$[213]$} \\
\hline Maklamicin & $\begin{array}{l}\text { Spirotetronate-class } \\
\text { polyketide }\end{array}$ & Micromonospora sp. GMKU326 & $\begin{array}{l}\text { Root of a leguminous } \\
\text { plant, Thailand }\end{array}$ & 2011 & - & {$[176]$} \\
\hline
\end{tabular}




\begin{tabular}{|c|c|c|c|c|c|c|}
\hline Anthracyclinones & Anthracyclinones & Micromonospora sp. & $\begin{array}{l}\text { Tunicate Eudistoma } \\
\text { vannamei }\end{array}$ & 2012 & - & [197] \\
\hline $\begin{array}{l}\text { Juvenimicin C, } \\
\text { 5-O-Alpha-L- } \\
\text { rhamnosyltylactone }\end{array}$ & Macrolides & Micromonospora sp. & Marine sample & 2013 & - & {$[92]$} \\
\hline Telomycin & $\begin{array}{l}\text { Macrocyclic } \\
\text { peptide lactone }\end{array}$ & M. schwarzwaldensis & $\begin{array}{l}\text { Soil, the Black Forest, } \\
\text { Germany }\end{array}$ & 2013 & Antibacterial activity & {$[240]$} \\
\hline Levantilide C & Macrolide & Micromonospora sp. FIM07-0019 & $\begin{array}{l}\text { Hallow coastal waters, } \\
\text { island of Chiloe, Chile }\end{array}$ & 2013 & Anticancer activity & [136] \\
\hline Neomacquarimicin & $\begin{array}{l}\text { Carbocylic } \\
\text { polyketide }\end{array}$ & Micromonospora sp. NPS2077 & Marine sponge, Japan. & 2014 & - & {$[273]$} \\
\hline
\end{tabular}




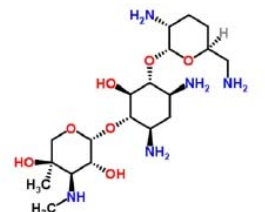

(A) Gentamicin $\mathrm{C}_{\mathrm{l}} \mathrm{a}$

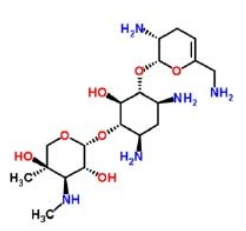

(B) Sisomicin

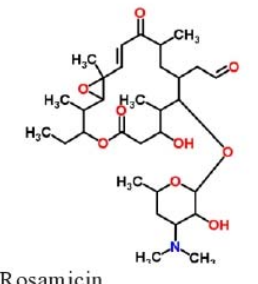

(C) Rosamic

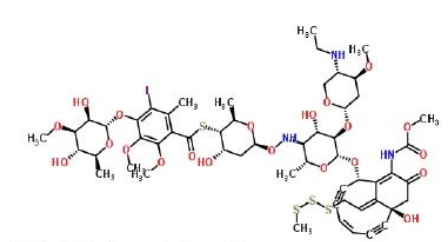

(D) Calicheamicin $\gamma$ II

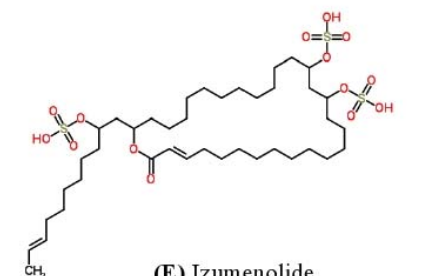

(E) Izumenolide
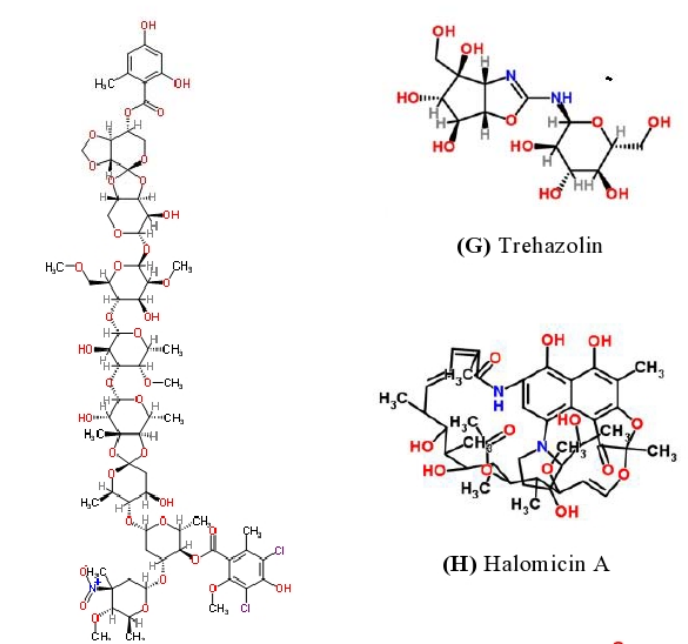

(G) Trehazolin

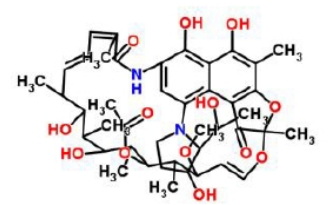

(H) Halomicin A

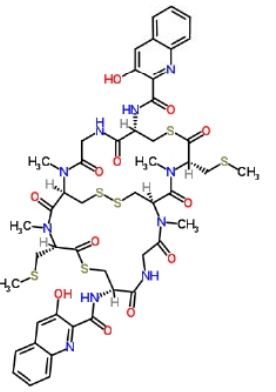

(I) Thiocoraline

(F) Evernimicin
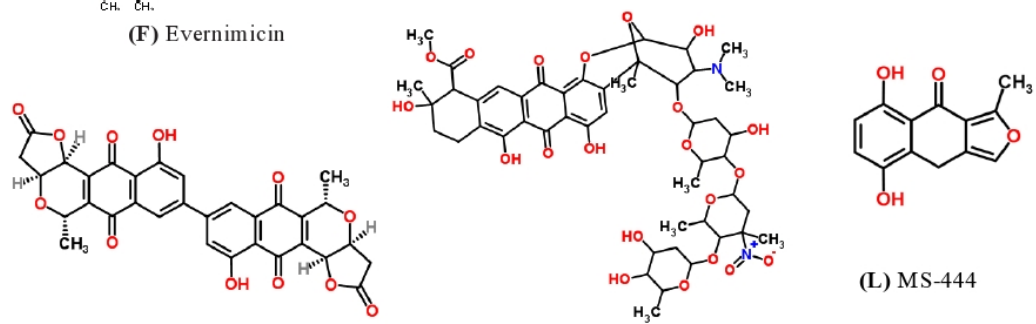

(K) Cororubicin 


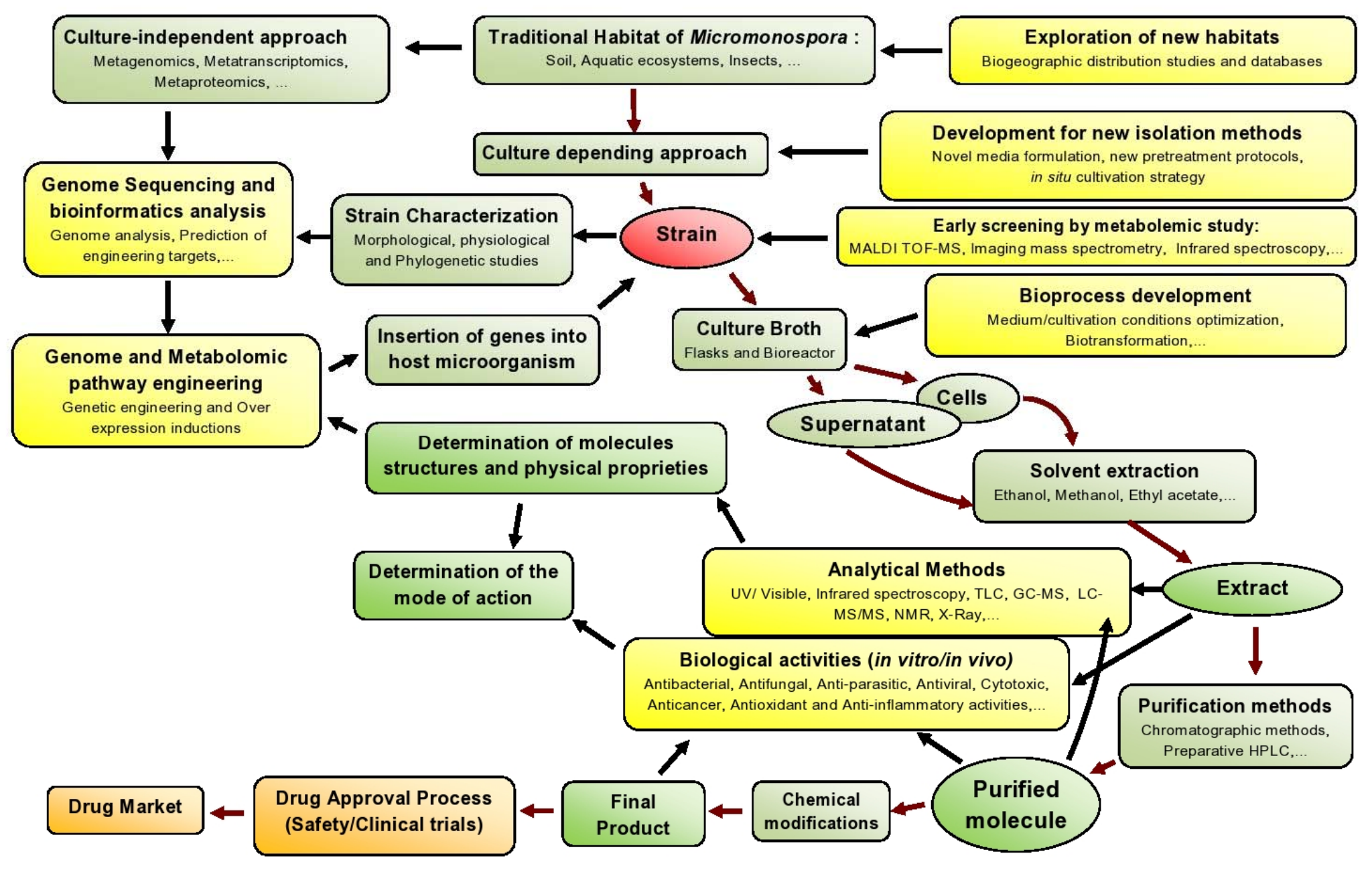

